
Digitized by the Internet Archive in 2011 with funding from

Boston Library Consortium Member Libraries

http://www.archive.org/details/civilrightswaron00almo 

Massachusetts Institute of Technology

Department of Economics

Working Paper Series

Civil Rights, the War on Poverty, and Black-White Convergence in Infant Mortality in the Rural South and Mississippi

\author{
Douglas Almond \\ Kenneth Y. Chay \\ Michael Greenstone
}

Working Paper 07-04

December 31, 2006

\author{
Room E52-251 \\ 50 Memorial Drive \\ Cambridge, MA 02142
}

This paper can be downloaded without charge from the 


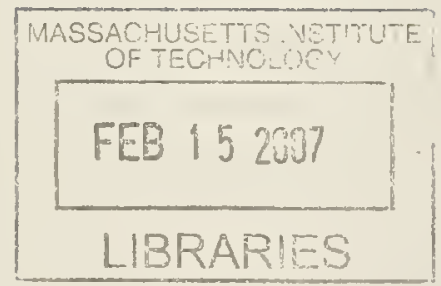




\title{
Civil Rights, the War on Poverty, and Black-White Convergence in Infant Mortality in the Rural South and Mississippi*
}

\author{
Douglas Almond, Kenneth Y. Chay, and Michael Greenstone
}

December 2006

\footnotetext{
* We thank Gary Becker, David Card, John DiNardo, Michael Grossman, Jon Gruber, Lars Hanen, James Heckman, Ted Joyce, Allen Lapey, Ellen Meara, Kevin Murphy, Derek Neal, Doug Staiger, Jill Quadagno, and seminar participants at Berkeley, Chicago, Harvard, MIT, and the NBER Summer Institute Child Studies Workshop for helpful comments. We are especially indebted to Dick Johnson and Harold Armstrong of the Mississippi State Department of Health, Joan Exline of the University of Southern Mississippi, Sarah Haldeman of the Lyndon B. Johnson Library, and Gary. Kennedy of the Bureau of Economic Analysis for their invaluable assistance with some of the data used in this study. Chuan Goh, Elizabeth Greenwood, Heather Royer, Stacy Sneeringer, and Paul Torelli provided excellent research assistance.
} 



\section{Civil Rights, the War on Poverty, and Black-White Convergence in Infant Mortality in the Rural South and Mississippi}

\section{$\underline{\text { Abstract }}$}

For the last sixty years, African-Americans have been $75 \%$ more likely to die during infancy as whites. From the mid-1960s to the early 1970 s, however, this racial gap narrowed substantially. We argue that the elimination of widespread racial segregation in Southern hospitals during this period played a causal role in this improvement. Our analysis indicates that Title VI of the 1964 Civil Rights Act, which mandated desegregation in institutions receiving federal funds, enabled 5,000 to 7,000 additional black infants to survive infancy from 1965-1975 and at least 25,000 infants from 1965-2002. We estimate that by themselves these infant mortality benefits generated a welfare gain of more than $\$ 7$ billion (2005\$) for 1965-1975 and more than $\$ 27$ billion for 1965-2002. These findings indicate that the benefits of the 1960s Civil Rights legislation extended beyond the labor marker and were substantially larger than recognized previously.

Douglas Almond

Department of Economics and SIPA

Columbia University

International Affairs Building, MC 3308

420 West 118 th Street

New York, NY 10027

and NBER

da2152@columbia.edu

Michael Greenstone

MIT Department of Economics

50 Memorial Drive, E52-391B

Cambridge, MA 02142

and NBER

mgreenst@mit.edu

\author{
Kenneth Y. Chay \\ Department of Economics \\ University of Califormia, Berkeley \\ 549 Evans Hall \\ Berkeley, CA 94720 \\ and NBER \\ kenchay@econ.berkeley.edu
}





\section{Introduction}

In 1965, 40 African American infants died for every 1,000 born in the U.S. - a rate comparable to current levels in India or Iran. Over the next ten years, the infant mortality rate among U.S. blacks fell to 24 per thousand. Among black infants born in 1975, roughly 7,000 more babies survived to age 1 than if the pre-1965 trend had continued. Further, the gap between black and white infant mortality rates (IMR) narrowed substantially during the late 1960s and early 1970s (Figure la). Indeed, these years comprise the sole period of large reductions in the black-white infant mortality gap since World War 11. ${ }^{1}$

In this paper we establish that much of the 1965-75 improvement in black infant health was driven by a sharp decline in post-neonatal mortality rates (PNMR) in the rural South. ${ }^{2}$ Figure $1 b$, for example, shows the number of post-neonatal deaths among black and white infants due to diarrhea and pneumonia in the state of Mississippi. In the early 1960s, post-neonatal death rates for these two causes were 6-7 times higher among blacks than whites and showed no trend toward relative improvement. Starting in 1966, however, the number of deaths due to these causes plummeted among black infants, while the number for whites remained nearly constant. This dramatic trend break in fatalities for these two causes is important because they contributed to a high fraction of overall black infant mortality and effective treatments for both conditions were well known and widely used.

We argue that the trend break in black IMRs in the rural South was driven by federally mandated desegregation efforts that increased access to hospital care for black infants. Of the events that led to the mandated desegregation, two stand out as central. The passage of Title VI of the Civil Rights Act in July 1964 prohibited discrimination and segregation in any institution receiving federal funds. Second, hospital eligibility for payments under the new Medicare program - begun July 1, 1966 - was conditioned on elimination of the racially discriminatory practices that were common at the time. Together, the Civil Rights Act and the financial leverage exercised by the Johnson administration led to the opening of previously "white-only" hospitals to blacks and the end of explicit racial segregation in health care.

\footnotetext{
1 The National Center for Health Statistics switched from coding race based on the infant's race to the race of the mother in 1990. Consequently, it is impossible to extend these series beyond 1990 in a consistent manner.

${ }^{2}$ Conventionally, infant mortality is defined as the death rate of infants within their first year of life. Post-neonatal mortality is the death rate in the period from 28 days to 1 year after birth. Neonatal deaths are those that occur in the first 28 days after birth.
} 
We implement a battery of tests to evaluate the hypothesis that hospital desegregation caused the large reductions in the black-white IMR gap. The results of these tests are strongly supportive. First, the reduction in the black-white IMR gap began immediately after integration and was largest in the rural South where blacks' access to hospitals was the most constrained. Second, within the rural South, the decline was concentrated among post-neonatal deaths, which were more preventable than neonatal fatalities at the time. Roughly two-thirds of the decline in relative PNMRs was due to a reduction in pneumonia and gastroenteritis deaths, two causes preventable by hospital treatment.

The most demanding test comes from a case study of Mississippi. Despite strong financial incentives provided by Medicare, many hospitals in Mississippi were slow to integrate. We evaluate the impact of those delays using an event-study approach that is based on detailed, hospital-level data on the timing of hospital compliance with Title VI. We find immediate and large reductions in post-neonatal mortality, especially among conditions most treatable in hospitals, when a hospital in the county of residence was certified as desegregated. These gains were not shared by white infants, and they are robust to adjustment for various alternative health determinants, such as maternal characteristics (e.g., age and marital status), transfer payments (including Food Stamps), Medicaid participation, and per-capita income. Further, the same approach finds an immediate and sharp increase in the fraction of black births in hospitals, which corroborates the validity of the federal governments' claims of successful integration. Thus, the evidence appears inconsistent with alternative explanations, including an innovation in medical technology or a change black infants' home environments.

Overall, our analysis indicates that this federally mandated desegregation of hospitals enabled over 5,000 black infants to survive until age 1 between 1965 and 1975 in the rural South and 25,000 through 2002. We estimate that the infant mortality benefits alone were equivalent to a welfare gain of $\$ 7.2$ to $\$ 11.1$ billion (2005\$) for blacks born in the rural South from 1965-1975. For the 1965-2002 period, we estimate gains between $\$ 27.5$ and $\$ 41.9$ billion. These findings indicate that the benefits of the 1960s Civil Rights legislation extended beyond the labor market outcomes considered previously (Chay 1995; Chay 1998; Donohue and Heckman 1991; Heckman and Payner 1989). Consequently, we conclude that the benefits of this legislation were substantially larger than has been recognized. 
The paper proceeds as follows. Section 11 provides a brief history of the federally mandated desegregation of hospitals. Section III uses state by urban/rural data to test the hypothesis that the mandated desegregation accounts for a substantial fraction of the improvement in the black-white IMR in the decade after 1965. Section IV reports on the Mississippi event study and its results. Section V interprets the results, and Section VI concludes.

\section{The Federally Mandated Desegregation of Hospitals}

\section{A. Segregation and Scarcity: Blacks' Access to Hospitals Prior to 1965}

Hospitals and other health facilities, which should be the institutions of healing, often because of discrimination become the means of shortening life.

(Robert Nash, Director of Office of Equal Health Opportunity, 1966)

The South was a deeply segregated society throughout the 1950s and early 1960s. This separation of races extended to all areas of life, including the provision of health services. A Journal of the National Medical Association survey of 523 hospitals administered in 1955-1956 found that while 87 percent of hospitals in the North had a "policy of integration", only 10 percent of hospitals in the South had one. Further, a 1956 survey of 2400 Southern hospital administrators found that only 17 percent were willing to accept desegregation, with 62 percent adamantly opposed, 10 percent favoring separate hospitals, and 11 percent unwilling to respond (Seham 1964). These policies continued into the early 1960s. A 1963 survey found that 85 percent of southern hospitals reported "some type of racial segregation or exclusion," compared to less than 2 percent in northern and western states (U.S. Commission on Civil Rights 1963:141). The pattern of discrimination usually "consisted of a separate wing or floor for Negro patients" in single-building hospitals (U.S. Commission on Civil Rights 1966:10).

A relatively unrecognized ${ }^{3}$ aspect of hospital segregation and exclusion in the South was the federal government's role in supporting it both legally and financially through the Hospital Survey and Construction Act of 1946, also known as the Hill-Burton Act. Two decades after its enactment, 350,000 hospital beds (or approximately half of the existing beds in the US) had been constructed under the HillBurton program. ${ }^{4}$ As Hill-Burton funding was more generous in poorer areas (DHEW 1966), the federal government was the dominant force in the postwar hospital construction in the South. The 1946

\footnotetext{
${ }^{3}$ Reynolds (1997) and Smith $(1999,2005)$ are notable exceptions.

${ }^{4}$ Almond et al. (2006b) estimate the infant health benefits of the Hill-Burton Act.
} 
legislation that enacted Hill-Burton explicitly invoked the principle of "separate but equal" with regard to race. This clause remained despite the fact that other parts of the legislation were amended and extended several times both before and after the 1954 Brown vs. Board of Education decision that "separate but equal" was unconstitutional. ${ }^{5,6}$ Moreover, the Hill-Burton program funded health care facilities that specifically excluded individuals on the basis of race. ${ }^{7}$ The Hill-Burton Act was the only federal legislation to codify racial segregation and exclusion since the 19th century (Smith 1999). As Seham noted in the New England Journal of Medicine in 1964, "To 20,000,000 citizens, discrimination and segregation followed" from the separate-but-equal clause of the Hill-Burton Act.

Table 1 presents evidence that black hospital patients in the rural South were tremendously underserved relative to whites through the early 1960s. Panel A of Table 1 reports the fraction of black infants born in hospitals with doctors present for $1955-1965$ by region. ${ }^{8,9}$ While black hospitalization rates for labor and delivery approached those of whites in the urban areas of the North and "Elsewhere" (largely the Midwest and West), large gaps existed in the South. For residents of the Rural South, $40 \%$ of black babies born were not born in a hospital with a doctor present, while the comparable figure for whites was only $4 \%$. The racial disparity was still larger in Mississippi: more than half of black infants

\footnotetext{
5 After the Brown decision, Hill-Burton program administrators repeatedly requested that the program cease following the "separate but equal" doctrine. For example, a February 1963 memo from the General Counsel at the Department of Health, Education, and Welfare to the Assistant Surgeon General states, "The acceptance of internal segregation at institutions which admit both races is also, $\mathrm{l}$ believe, in accord with the intent of Congress at the time when the legislation was enacted, and in this respect also Congress has made no change to the law" (DHEW memo February 12, 1963:1). This memo goes on to argue that Hill-Burton "administrative officers" have no choice but to continue to award grants to segregated health care facilities "despite any doubts they individually may entertain regarding the constitutional validity of the statutes" (ibid).

${ }^{6}$ As late as August, 1963, the U.S Senate rejected a proposal that would have required grants under the Hill-Burton Act to hospitals that did not discriminate on the basis of race (U.S. Court of Appeals Fourth Circuit 1963:23)

${ }^{7}$ A hospital constructed with Hill-Burton money could exclude a race outright if it had indicated in its application that "certain persons in this area will be denied admission to the proposed facilities as patients because of race, creed, or color" and reported to the Surgeon General that other facilities for the excluded race were available (U.S. Court of Appeals Fourth Circuit 1963:7). A total of 89 hospital construction projects in 14 states were approved with the stipulation that only one race would be admitted to the facility (U.S. Commission on Civil Rights 1963:130131). Ninety percent of the funds for these discriminating facilities went to all-white facilities.

${ }^{8}$ This is the only measure of hospital access available from the vital statistics data.

9 We define the "Rust Belt" states as Illinois, Michigan, New York, Ohio, and Pennsylvania. The South is comprised of 17 states (including Washington DC), as assigned by the US Census Bureau. We refer to nonmetropolitan and metropolitan counties as the "rural" and "urban" areas of a state. With the exception of New England, counties are classified as "metropolitan" if they are included in a Census Bureau-defined Standard Metropolitan Statistical Area (SMSA). Race was coded as white and non-white in the Vital Statistics data in this period. In 1968, the non-white category was subdivided and we found that blacks accounted for $99 \%$ of nonwhite infant deaths in the Urban Rustbelt, Urban South, Rural South, and Mississippi. The comparable figure for Urban Elsewhere is $93 \%$. We exclude Rural Elsewhere from the analysis because blacks only accounted for $52 \%$ of nonwhite infant deaths in this area.
} 
were born outside hospitals, versus $2 \%$ of whites.

Panel B uses data on the number of hospital beds available for white and "colored" patients collected by the Mississippi Commission on Hospital Care. ${ }^{10}$ The number of hospital beds per 1,000 births allocated to blacks versus whites in the early 1960 s is reported. ${ }^{11}$ This measure of access to hospital care is relevant because certain life-saving treatments for infants were only available at hospitals. More than twice as many hospital beds were available to whites as blacks in the predominantly white counties. More than five times as many hospital beds were available to whites as blacks in the predominantly black counties of Mississippi. ${ }^{12}$

Low hospitalization rates and bed ratios reflected the inferior medical care available to blacks under segregation. Senator Javits of New York stated to the U.S. Senate: "Segregated hospitals and segregated wards have resulted in over-crowded conditions and substandard facilities for many Negro patients," who are often "relegated to basement and attic wards." Javits further noted that: "Often when Negro wards are filled, no additional Negro patients are admitted even though there may be empty beds elsewhere in the hospital." (Javits 1962).

\section{B. The End of Legalized Segregation in Health Care Facilities}

Jim Crow was a persistent feature of southern hospitals well into the $1960 \mathrm{~s}^{13}$ Below, we highlight three landmark events of the mid-1960s that were instrumental in ending racial segregation in the American healthcare system. These events involved all three branches of government in turn: judicial, legislative, and executive.

${ }^{10}$ That such data were collected annually reflects the degree to which racial segregation was institutionalized in Mississippi. Through 1964, Mississippi State law required that in hospitals "maintained by the State for treatment of white and colored patients," hospital administrators must provide separate entrances for whites and blacks and that the entrances "shall be used by the races only for which they are prepared." Further, the Governor of Mississippi was empowered to remove any administrator failing to comply with this law (Dept. of Health Education and Welfare memo, June 26, 1964:6). Mississippi was the only state in the nation that required segregation in state-run hospitals (DHEW memo, January 31, 1956).

${ }^{11}$ We have beds data by race for $1960,1962,1963$ and 1964 and compute the ratio to births occurring in these years.

${ }^{12}$ The finding of greater disparities in access in the predominantly black counties is similar to Bond's (1939) study that demonstrates that black schools were of a higher quality in counties where blacks formed a smaller fraction of the population. We thank an anonymous referee for pointing this out.

13 There was even evidence that Southerners' commitment to this system was growing as a reaction to the burgeoning Civil Rights movement. Caro (2002) argues that the early stages of the Civil Rights movement in the 1950 s led to increased violence by whites against blacks and a renewed focus on preserving the system of segregation (see especially Chapter 33 ). 
First, in 1963, Dr. George Simkins, a black dentist in Greensboro, North Carolina, joined with black patients and other physicians in suing two hospitals which denied blacks admission and staff privileges. These hospitals, although private, had received federal Hill-Burton construction funds. In November 1963, the Fourth Circuit Court of Appeals decided Simkins v. Moses H. Cone Memorial Hospital in favor of the plaintiffs. The court declared that the section of the Hill-Burton legislation permitting "separate-but-equal" health facilities was unconstitutional. ${ }^{14}$ Furthermore, the majority opinion stated: "Racial discrimination in medical facilities is at least partly responsible for the fact that in North Carolina the rate of Negro infant mortality is twice the rate for whites..." (U.S. Court of Appeals Fourth Circuit 1963:14) 15

In March 1964, the Supreme Court declined to review the Appeals Court decision, leaving it in place. The immediate result of this decision was that new applications for Hill-Burton funds and pending projects were all required to be nondiscriminatory with respect to admissions, staff privileges, and access to all portions of the facilities (Smith 1999). Since half of all Hill-Burton grantees were private, nonprofits (DHEW February 12, 1963), this ruling's impact was not simply limited to public health facilities. However, this ruling did not affect segregated hospitals that had previously received Hill-Burton funding. ${ }^{16}$ In fact, lawmakers cited the Simkins case as demonstrating the need for definitive federal legislation.

Passage of Title VI of the Civil Rights Act in July 1964, which prohibited discrimination and segregation in any institution receiving federal funds, was the second landmark event. ${ }^{17}$ According to the bipartisan U.S. Commission on Civil Rights, "Seldom has any piece of legislation been so broad in scope, sweeping across departmental, geographical and political lines, as Title VI of the Civil Rights Act of 1964" (U.S. Commission on Civil Rights 1966:1). The passage of the legislation by itself led to a substantial integration of hospitals in the South during the remainder of 1964 and 1965 . However, there

\footnotetext{
${ }^{14}$ Reynolds, 1997 refers to Simkins as "the Brown case for hospitals."

${ }^{15}$ This view was also expressed by the medical community. For example, see Seham (1964) in the New England Journal of Medicine and Nash (1968) in the American Journal of Public Health.

${ }^{16}$ According to the 1963 survey by the U.S. Commission on Civil Rights, $60 \%$ of segregated health facilities had received Hill-Burton funds: Reynolds (1997).

${ }^{17}$ In particular, Title Vl stipulated that "Patients must be admitted to facilities without regard to their race, creed, color, or national origin. Once admitted, patients must have access to all portions of the facility and to all services without discrimination. They may not be segregated within any portion of the facility, provided a different service, restricted in their enjoyment of any privilege, or treated differently because of their race, creed, color, or national origin" (Reynolds 1997: 1852).
} 
remained pockets of noncompliance in some hospitals and in some practices (e.g., integration of patients within wards), even within hospitals that claimed to comply with Title VI (ibid).

The final event was the inception of the Medicare program in July 1966. Following directions from President Johnson, eligibility for Medicare reimbursement required that hospitals end racial discrimination. ${ }^{18}$ One observer has noted: "...Medicare payments to hospitals promised to be generous, and thereby essential. In essence, hospitals had to choose between affluence through compliance and bankruptcy" (Smith, 2005:320). ${ }^{19}$ Further, in the months leading up to July, a "Children's Crusade" of 750 federal employees under the Office of Equal Health Opportunity worked to ensure hospital compliance with Title VI through on-site inspections (Smith 1999:113). ${ }^{20}$

By June 30, 1966, 92 percent of all hospital beds were in compliance with Title VI (Ibid:141). In July and through the fall of 1966, the Office of Equal Health Opportunity worked to secure compliance in the remaining hospitals. ${ }^{21}$ This "quiet revolution" meant that in southern hospitals: "Negroes are being admitted and treated as anyone else for the first time" (Nash 1968:246) Notably, Mississippi hospitals were among the most intransigent to these changes, which we exploit in the below analysis.

\section{Gastroenteritis, Pneumonia, and the Black-White Mortality Gap}

Prior to the development and diffusion of technologies benefiting premature and low-weight infants during the $1970 \mathrm{~s}$ and $1980 \mathrm{~s}^{22}$ medical care was most successful in preventing deaths during the post-neonatal period (1-12 months after birth). Post-neonatal deaths tended to be caused by negative

\footnotetext{
${ }^{18}$ In a speech to the American public the night before Medicare went into effect, Johnson said, "Medicare will succeed-if hospitals accept their responsibility under the law not to discriminate against any patient because of race" (quoted in Reynolds 1997). Also see Quadagno (1999).

${ }^{19}$ The former director of the Mississippi State Hospital Association, Thomas Logue, referred to the early Medicare program as a "gold mine" for Mississippi hospitals.

${ }^{20}$ Robert Nash (Director of Office of Equal Health Opportunity, PHS) wrote about the process of enforcing integration of health care facilities, "Some people have compared our administration of Title VI to the practices of some of the world's outstanding dictatorships" (Nash 1968: 251).

${ }^{21}$ Reynolds (1997) quotes Wilbur Cohen, who as the Secretary of HEW was a principal architect of the Medicare legislation: "There is one other important contribution of Medicare and Medicaid which has not yet received public notice-the virtual dismantling of segregation of hospitals, physicians offices, nursing homes, and clinics as of July 1 , 1966....If Medicare and Medicaid had not made another single contribution, this result would be sufficient to enshrine it as one of the most significant social reforms of the decade [if not the century]."

${ }^{22}$ Two key changes in the treatment of neonates during the past 40 years were the advent of respiratory therapy techniques and improvements in mechanical ventilation in the 1970 s and the introduction of surfactant therapy in 1989. Further, most of the diffusion of local specialized neonatal intensive care units (NICUs) occurred in the 1980 s.
} 
events after birth, usually infectious diseases and accidents (Grossman and Jacobowitz 1981). For pneumonia and gastroenteritis infections in particular, death could be prevented with timely medical treatment, ${ }^{23}$ in part a result of greater availability of antibiotics following World War II (Shapiro et al, 1968). Antibiotics were administered intravenously, together with fluids, in hospitals.

Prior to World War II, pneumonia and gastroenteritis accounted for half of post-neonatal deaths for blacks and whites alike. ${ }^{24}$ By 1965 , these two causes accounted for under a third of white postneonatal deaths while still comprising $45 \%$ of black post-neonatal deaths. The postwar surge in hospital capacity financed by the Hill-Burton Program succeeded in reducing infant mortality, but these benefits were concentrated among whites (Almond et al. 2006b). By 1965, blacks were four times as likely to die from gastroenteritis and pneumonia in the post-neonatal period as whites. Thus, the primary factor underlying the widening black-white infant mortality gap after 1947 (see Figure la) was the divergence in black and white experiences with these two eminently treatable afflictions.

\section{Implications}

This paper's goal is to assess whether the federally mandated integration of health care facilities caused at least part of the improvement in black infant mortality rates documented in Figure la. In the absence of a randomized experiment, we proceed by presenting a series of increasingly demanding tests. Specifically if there is a causal relationship, then the above historical context suggests that the data will fail to reject the following hypotheses about the decline in the black IMR after 1965:

I. It should exceed the decline in the white IMR.

2. It should disproportionately occur in the areas of the country where segregation and inadequate supply were more pervasive.

3. It should disproportionately occur among causes of death that are more responsive to access to hospitals.

4. Among the causes of death that are preventable with hospital access, it should respond quickly to integration.

The remainder of the paper implements tests of these four hypotheses and fails to reject them.

\section{Regional Evidence on the Consequences of the Mandated Desegregation of Hospitals}

\footnotetext{
${ }^{23}$ With regard to gastroenteritis, Emery (1976:204) writes that the mortality rate relates to "the earliness [or] lateness of diagnosis and admission to hospital." Similarly for pneumonia, a 1964 pediatrics textbook states: "The outcome is dependent upon early diagnosis and the appropriateness of [medical] treatment" (Nelson 1964:847-848).

${ }^{24}$ Shapiro et al. (1968): Appendix tables 1.2d and 1.2e.
} 
There is no question that if the same care were available to Negroes in Mississippi and other Southern states as in Minnesota and other Northern states, Negro morbidity and mortality rates could be sharply reduced.

A. Data

(Max Seham, New England Journal of Medicine: 1964)

Surprisingly few studies exist of long-run trends in the relative health of black infants over time. In addition, the existing research is based on highly aggregated data, both across regions and over time, which provide little information on the precise location and timing of infant mortality changes by race. Consequently, evidence on the specific factors underlying significant changes in black-white infant health outcomes is sparse and often anecdotal.

To document the location and timing of improvements, we entered data from the 1955-1975 publications of the Vital Statistics of the United States. Drawn from standard certificates of live birth and death, they cover the universe of births and deaths in the United States in each year. We entered annual, race-specific (white and non-white) series for rural and urban areas of each state. Our focus is on infant mortality rates, the ratio of infant deaths within a year of birth to the total number of live births in that year (expressed as deaths per 1,000 live births), and we also distinguish between deaths in the neonatal and post-neonatal periods. As discussed in the previous section, we focus on the Rural South, Urban South, Urban Rustbelt, Urban Elsewhere, and Mississippi. ${ }^{25}$

We also obtained individual-level electronic mortality data for the years $1960-1975 .^{26}$ Unfortunately, analogous natality micro-data are available only beginning in 1968. Nevertheless, we can use the 1960-75 mortality microdata together with natality data aggregated by urban and rural regions of each state. This enables us to analyze trends in mortality rates due to pneumonia and gastroenteritis. These causes accounted for $39 \%$ of all postneonatal fatalities in the $1960-65$ period.

\section{B. Trends in Black-White Infant Mortality Rates by Region, 1955-1975}

Figure 2 plots the difference in black and white infant mortality rates by region for the years 1955-1975. Clearly, large gaps in infant mortality rates existed throughout the country. In the first half

\footnotetext{
${ }^{25}$ Almost 80 percent of all nonwhite births from $1955-75$ were in either the South or the urban counties of the Rust Belt states. The Urban Elsewhere counties accounted for another 16 percent. During the period, 28 and 26 percent of all births in the rural and urban South, respectively, were nonwhite; compared to 17 percent in the urban Rust Belt and 11 percent in all other urban counties.

${ }^{26}$ See Data Appendix.
} 
of the period, the difference between black and white infant mortality rates displays no obvious pattern -remaining roughly constant in some regions and actually expanding in others. Between 1965 and 1975, however, the racial gap narrowed in all regions. The timing of this convergence is consistent with our hypothesis that federally mandated integration of health care facilities begun in the mid-1960s caused an improvement in black infant mortality rates.

Examination of the regional patterns in mortality gaps provides a more demanding test. Specifically, we expect that the decline should be greater in regions where segregation and restricted access were pervasive. Again, these mortality series support this prediction. For example among the four regions, the largest decline from 1965-1975 occurred in the Rural South, where the pre-existing disparities in access were the greatest (recall Table 1). In this region, the racial gap declined by 11.4 deaths per 1,000 births, closing fully half of the initial disparity. To put this number in context, it means that 4,700 more black infants born in 1975 survived to age 1 than if the 1965 black-white difference still held in $1975 .^{27}$ In Mississippi, where pre- 1965 access differences were especially glaring, the decline was 16.4 deaths per 1,000 births. $^{28}$

Finally, trends in the racial gap outside the South track each other well throughout the entire period. These regions also experienced a narrowing of the racial gap in the $1965-75$ period, albeit $35 \%$ $40 \%$ smaller than the decline in the Rural South. The next two subsections further probe the validity of our hypothesis by estimating trend break models by region and decomposing the mortality improvement into categories believed more and less responsive to hospital access.

\section{Trends in Black-White Infant Mortality Rates by Age and Region, 1955-1975}

If the equalization of hospital access between blacks and whites indeed caused the black-white infant mortality gap to fall, we would expect this reduction to be concentrated in the post-neonatal period. To evaluate this possibility, we fit simple trend break regression models of the following form:

$$
\mathrm{y}_{\mathrm{sr}}=\alpha t+\beta(t-1965) * 1(t>1965)+\delta_{\mathrm{sr}}+\varepsilon_{\mathrm{srt}},
$$

where $s, r$, and t index state, urban/rural, and year, respectively. The dependent variable is the neonatal or

\footnotetext{
${ }^{27}$ Calculated as: \# of Black Births ${ }^{1975} *\left(\right.$ Black $1 \mathrm{MR}^{1965}$-(White $1 \mathrm{MR}^{1965}$-White $\left.1 \mathrm{MR}{ }^{1975}\right)$ ), for rural South births.

${ }^{28}$ In the rural South and Mississippi, the black-white gap was increasing from 1955-1965.
} 
postneonatal mortality rate. The equation is estimated separately for blacks, whites, and the black - white difference. The explanatory variables are a time trend, $t$, and an indicator variable equal to one if the year is after 1965 interacted with a post-1965 time trend equal to $(t-1965)$. $\alpha$ measures the average 1955-65 trend in the infant mortality rate across states. $\beta$ is the parameter of interest and measures the average slope change in the 1MR trend that occurred after 1965. All specifications include rural/urban by state fixed effects, $\delta_{\text {sr }}$, which account for permanent differences across rural/urban areas of states. The numbers of births in each race-rural/urban-state-year cell are used as weights in the race-specific regressions, and the weight is the number of black births in the black-white regressions. The standard errors are corrected for heteroskedasticity and residual time-series correlation at the state-level.

Table 2 presents the trend break regression results for post-neonatal and neonatal mortality rates in the two sets of columns. Within each set of columns, results for black and white mortality rates and the black-white difference are shown, although we focus our description here on the difference regressions in columns (1c) and (2c) due to space constraints. The panels of the table correspond to the four regions in Figure 2 and Mississippi.

The rural South stands out for several reasons. First, the pre-1965 black post-neonatal mortality rate exceeded the white rate by 15.2 deaths per 1,000 live births. This racial difference exceeded the average black post-neonatal mortality rate in each region outside the South. Second, the estimates show that the gap between black and white post-neonatal mortality rates was increasing from 1955 to 1965 at the rate of 0.18 deaths (per 1,000 live births) per year. Thus, conditions for blacks were apparently deteriorating relative to whites.

Third, there was a large trend break of about 1.4 deaths per year after 1965 . This implies that the black-white mortality gap in the rural South decreased 14 deaths per 1,000 births more through 1975 than if the pre-1965 trend had prevailed. This improvement is comparable to the pre-existing racial gap. Moreover, it implies that 5,900 additional infants survived to year 1 through 1975 than would have been expected from pre-1965 trends.

The racial gap in post-neonatal mortality rates also narrowed in the other three regions. However, the black-white trend break in the rural South is 2.5 times larger than in the Urban South, 5 times larger than in the Urban Rustbelt, and 9 times larger than in the Urban Elsewhere. Among these regions, the 
magnitude of the trend break corresponds to the deficiencies in hospital access in Table 1: largest in the urban South followed by the urban rustbelt and urban elsewhere. Finally, we note that the largest blackwhite trend break after 1965 was for Mississippi, where access gaps werc greatest.

After 1965, both whites and blacks enjoyed improvements in neonatal mortality, although blacks' gains were larger. 1nterestingly, the closing of the racial gap was roughly equivalent across the four regions. Further, for blacks in Urban areas outside the South, the post-1965 reductions in neonatal mortality exceeded the post-neonatal ones. ${ }^{29}$ For present purposes, we note that the largest reductions in both mortality and black-white gaps were achieved during the post-neonatal period, and that the magnitude of post-neonatal improvements corresponds to available measures of hospital access. ${ }^{30}$

\section{Trends in Black-White Infant Mortality Rates by Cause of Death and Region, 1960-1975}

Table 3 present analogous trend break results for the subset of post-neonatal deaths caused by pneumonia and gastroenteritis. As noted, we isolate these deaths because they were readily and necessarily treated in hospitals at the time. Because the data reporting cause of death are available beginning in $1960,{ }^{31}$ column (1) reports trend-break estimates for all post-neonatal deaths when the preperiod is restricted to $1960-1965$. This permits assessment of the extent to which treatable causes account for the post-neonatal trend breaks in Table 2.

Estimates in columns $(2 a)-(2 c)$ indicate that large reductions in preventable deaths occurred in the South that dwarfed improvements for whites. Moreover, the decline in deaths due to these causes accounted for roughly two-thirds of the entire relative decline in the post-neonatal mortality gap. The pattern for Mississippi is similar. Thus, although gastroenteritis and pneumonia accounted for under half

\footnotetext{
${ }^{29}$ A comprehensive accounting of neonatal mortality trends (especially in Mississippi) is beyond the scope of this paper, however they are likely to be at least partially due to the initiation of the Food Stamps program (Almond et al. 2006a) and the extension of the Matemal and infant Care Component of the Matemal and Child Health Services Program (Chay and Greenstone 2000; Gold, et al. 1969; Sokol et al. 1980; Peoples and Siegel 1983; Chabot 1971).

${ }^{30}$ Chay and Greenstone (2000) show that this measure of access was increasing in the years prior to 1965 for rural southem blacks, but this trend accelerated after 1965. In regression specifications analogous to those underlying Tables 2 and 3 for the fraction of births in hospitals, the estimated post-1965 trend break for blacks in the rural South is large and significant. To the extent that this measure reflects the availability of hospital care to black infants after 1965, this availability improved at the time when post-neonatal mortality rates for Southern blacks began to fall. See Chay and Greenstone (2000) for evidence on the significant and positive association between the mortality improvement and the share of births in hospital.

${ }^{31}$ See Data Appendix.
} 
of post-neonatal deaths by the mid-1960s, ${ }^{32}$ they accounted for most of the post-neonatal mortality improvement for blacks. In contrast, there is little evidence of a decline in these deaths in the Urban South and Urban Rustbelt. ${ }^{33}$

\section{Event Study Evidence of the Impact of Integration on Infant Health and Hospital Access}

\section{A. Event Study Evidence}

We now tum to the most direct and demanding test of the integration hypothesis, conducted with a new data file compiled for this purpose. Medicare certification dates for the roughly 100 Mississippi hospitals were obtained from the Journal of the American Hospital Association annual guides issues. We combined these data with annual, race-specific county-level vital statistics data for Mississippi, including the number of neonatal and post-neonatal fatalities by broad cause of death categories, the number of births in a hospital with a doctor present, total births, the distribution of births by maternal age (under 15 , $15-19,20-29,30-34$, and 35 or older), and the fraction of "illegitimate" births. ${ }^{34}$ Finally, we compiled county-level data on federal transfer payments, broken out by categories (e.g. Food Stamps) and countylevel income per-capita. See the Data Appendix for further details.

We implemented an event-study analysis of the impacts of the presence of at least one Medicarecertified hospital in a county on infant health and hospital access using these data. Specifically we fit the following equation:

$$
\mathrm{y}_{\mathrm{ct}}=\alpha_{\mathrm{c}} t+\sum_{\mathrm{i}=1}^{6} \pi_{\mathrm{i}} \mathrm{l}\left(\tau_{\mathrm{ct}}=\mathrm{i}\right)+\mathrm{X}_{\mathrm{ct}}{ }^{\prime} \beta+\eta_{\mathrm{c}}+\xi_{\mathrm{ct}},
$$

where $\mathrm{c}$ references county and $\mathrm{t}$ indexes year. $\tau$ denotes the event year, and it is normalized so that for each county $\tau=1$ in the first full year that the first hospital within its boundaries is certified as Medicare eligible. Among the 80 Mississippi counties with complete data, ${ }^{35} \tau=1$ for 47 counties in 1967,11 in

\footnotetext{
${ }^{32}$ For 1964-1966, gastroenteritis and pneumonia accounted for $43 \%$ of all post-neonatal deaths in the rural South, and $37 \%$ of post-neonatal deaths nationally. Among blacks, these causes accounted for $49 \%$ of post-neonatal deaths in the rural South and $45 \%$ nationally.

${ }^{33}$ The entire decline in post-neonatal fatalities among urban Elsewhere residents, while substantially smaller than in the rural South and Mississippi, is accounted for by fewer preventable deaths. This finding is an interesting subject for future research.

${ }^{34}$ For 1959-1970, we obtained these vital statistics data by filing a freedom of information act request with the Mississippi State Department of Health. We then extended these data through 1975 with the publicly-available Natality and Mortality Vital Statistics data files.

${ }^{35}$ Vital statistics data for Blacks in Itawamba and Tishomingo counties were unavailable.
} 
1968,5 in 1969 , and 17 in $1970 .^{36}$ Data from each county are restricted to the 13 years running from the seven years before a county's first hospital was certified for Medicare through six years afterward (i.e., -6 $\leq \tau \leq 6)$

The dependent variables are the post-neonatal mortality rate for all causes and for preventable (i.e., pneumonia and gastroenteritis) causes among county residents. We also use the percent of births in hospitals with a doctor present as a dependent variable to test for differential changes in hospital access by race as an implicit "first-stage" test of the integration hypothesis. A failure to find increased access for blacks would undermine the claim that greater access caused the improvement in infant health documented in this subsection.

Equation (2) includes a time trend that is allowed to vary at the county level (i.e., $\alpha_{c}$ ). The vector $\mathrm{X}_{\mathrm{ct}}$ includes the fraction of mothers in the five age categories listed above, the fraction of mothers that were unmarried, county-level per-capita income, and county-level per-capita transfer payments (net of medical insurance payments). ${ }^{37}$ The specification also includes fixed effects for each county (i.e., $\eta_{c}$ ). The equation is estimated separately for blacks, whites, and the black-white difference and it is weighted by the number of black, white, and black births, respectively. $\xi_{c t}$ is the stochastic error terms. Finally, the standard errors are corrected for heteroskedasticity and clustering at the county-level.

The parameters of interest are the six $\pi_{i}$ 's. They separately test for mean shifts in county-level post-neonatal mortality rates (and hospital access), after adjustment for pre-existing trends and the broad set of covariates, in each of the six years subsequent to the first certification of a hospital for Medicare in the county. This event study approach provides a rigorous test of the integration hypothesis -- that black post-neonatal fatalities were caused by racial discrimination in hospitals and that blacks' access to hospitals was restricted. An immediate and persistent intercept shift would provide strong evidence in favor of the integration hypothesis. If instead the infant mortality and hospitalization rates were not associated with certification, took a number of years to become evident, evaporated soon after certification, or began prior to certification, the validity of the integration hypothesis would be undermined.

\footnotetext{
${ }^{36}$ See Data Appendix for a description of how counties were assigned Medicare certification dates.

${ }^{37}$ Both income and transfer payments are interpolated in missing years. However, data coverage is best during the period of certification for the Medicare program.
} 
Table 4 presents the results from fitting equation (2) for the three dependent variables. It reports results from a parsimonious specification that includes just the time trend and the $\operatorname{six} l\left(\tau_{\mathrm{ct}}=\mathrm{i}\right)$ indicators, and the full specification described above (and in the row headings of Table 4). Panels A and B give the results for black and white infants, respectively.

Figure 3 summarizes the post-neonatal mortality results graphically. Specifically, it is based on the estimation of a version of equation (2) for the black-white difference in the post-neonatal mortality for all causes and, separately, preventable causes. The specification's only covariates are a full set of eventtime indicators, and their associated parameters are plotted. The vertical line divides the years before and after Medicare certification.

The table and figure provide dramatic support for the integration hypothesis. There is little evidence of a trend in either all cause or preventable cause post-neonatal mortality rates in the years preceding Medicare certification. In the first year after certification, the black all cause post-neonatal mortality rate declined by about 6 deaths (per 1,000 live bitths). This is greater than a $25 \%$ reduction in the black post-neonatality mean (for $\tau=0$ ) in a single year. By the end of the event-window, the decline is roughly 13 deaths (per 1,000 live births) which is more than a $50 \%$ decline. The preventable cause post-neonatal mortality rate estimates suggest that reductions in these fatalities accounted for $40 \%-45 \%$ of the overall post-neonatal decline.

Notably, the adjustment for the full set of covariates has no substantive impact on the estimated coefficients. ${ }^{38}$ Thus, the observable relative risk characteristics of black mothers cannot explain the column (la) results. ${ }^{39}$ Further, the black-white difference shown in Figure 3 leads to nearly identical conclusions; this undermines the possibility that the introduction of a health technology available to both races or other secular shocks explain the results.

Finally, columns (3a) and (3b) provide an opportunity to assess whether Title VI of the Civil Rights Act and the Medicare certifications achieved their most basic goal of increasing blacks' access to hospitals. It is tempting to treat the measured variable as the endogenous variable in an equation for post-

\footnotetext{
${ }^{38}$ The addition of year fixed effects to the richer specification in columns $(1 \mathrm{~b})$ and $(2 \mathrm{~b})$ leads to the same qualitative conclusions. However, the standard errors on the event time indicators are substantially larger due to the difficulty of separately identifying the year and event time fixed effects with the modest variation in Medicare certification dates.

${ }^{39}$ The share of black mothers who were teenagers or unmarried increased in Mississippi during the late 1960s.
} 
neonatal mortality (with certification as the instrument), but this would be inappropriate since the percentage of births in a hospital do not directly affect deaths in the post-neonatal period, especially those due to preventable causes. ${ }^{40}$ Nevertheless, it is telling that the entries document a large and precisely estimated increase in the percentage of black births occurring in hospitals as soon as one year after Medicare certification. Notably, there was a substantial pre-existing upward trend in births in hospitals among blacks. However, even after accounting for this trend, the percent of blacks born in a hospital was more than 12 percentage points (20 percent) higher three years after certification.

\section{B. Alternative Explanations}

For another factor to explain the post-neonatal mortality results, it would have to exert an immediate effect on post-neonatal deaths (especially among preventable causes) and vary across Mississippi counties in the same way as the Medicare certification dates. These are demanding criteria. Nevertheless, this subsection briefly considers alternative explanations for the paper's findings, in particular the major changes in social welfare and public health programs resulting from the War on Poverty.

The Medicaid program, initiated in 1966, provided money to poorer families for medical care. However, Mississippi did not begin its participation in Medicaid until January 1, 1970, by which time most of the reductions in black post-neonatal mortality in Mississippi had already occurred. Similarly, over this period the AFDC program appears to have played a much smaller role in Mississippi than in other states. ${ }^{41}$ Moreover, our event-study estimates are essentially unchanged by adjustment for countylevel transfer payments, including both AFDC and Food Stamp payments. ${ }^{42}$

Neither do programs that specifically targeted public health appear important for Mississippi

\footnotetext{
${ }^{40}$ We attempted to obtain annual counts of infant admissions during the 1960s by race and age (along with information on the principle diagnosis) from several of the larger Mississippi hospitals. Despite our offer to bear the cost of producing these data and redacting all personal identifiers, our requests were repeatedly denied.

${ }^{41}$ For example, caseloads in Mississippi grew at less than half the national rate between 1965 and 1970 (Department of Health and Human Services 1998:22). According to the BEA's government transfer payments data in the REIS file, there were no payments from the AFDC program to Mississippi until after 1968.

${ }^{42}$ Separate work in progress finds that the Food Stamps Program (FSP) national roll-out during the late 1960 s and early 1970s did improve certain perinatal outcomes (e.g. gestation length). However, no discernible effects were found for post-neonatal mortality (while no distinguishable from the zero, the point estimates were positive, i.e. FSP associated with an increase in PNMR). Moreover, no association was found between county-level adoption of FSP and births in hospital: Almond et al. (2006a).
} 
during this period. Real federal spending under the Maternal and Child Health $(\mathrm{MCH})$ program increased only 17 percent in Mississippi between 1965 and 1970 (DHHS 2001:80), and MCH expenditures (per poor child) in Mississippi were less than half the national average in 1969 (Davis and Schoen 1978:146). ${ }^{43}$ Also, while the proliferation of community health centers during the 1970 s has been found to decrease infant mortality, especially among blacks, there were only 51 such centers in the entire nation as of 1968 (Goldman and Grossman 1988). Further, community health centers did not provide the aggressive medical treatment that would have been required by infants with pneumonia and diarrhea.

Finally, changes in birth technology do not coincide with the timing of the infant mortality reductions for blacks in Mississippi (see footnote 22). Moreover, technological innovations are widely thought to impact early infant death resulting from premature and low birth weight births, which is not consistent with the striking reduction in preventable post-neonatal infant deaths among blacks in Mississippi.

In summary, we are unable to identify a viable alternative explanation for the event study results. Our conclusion from the Mississippi data is that the federally mandated integration of health care facilities played a central role in the sharp decline in blacks' post-neonatal mortality rates. To put the results in some context, the Table 3 estimates imply that just 6 years after successful integration, 270 additional black post-neonates per year survived to age 1 in Mississippi.

\section{Interpretation}

How large was the mortality reduction caused by mandated integration and what was the associated welfare gain? Answering these questions requires additional assumptions, but informs the importance of the health effects here documented and how they compare with effects from other government interventions.

The case for a causal impact of mandated integration is strongest in the rural South (where exante access disparities were greatest) and for causes of death known to be treatable in hospitals. The black-white preventable cause post-neonatal estimates in column (1) of Table 3 indicate a trend break of 0.66 deaths per 1,000 births lower in 1966 than predicted by pre-existing trends, 1.32 per 1,000 births

\footnotetext{
${ }^{43}$ Refers to "Title V Health Program totals or the MCH Block Grant totals."
} 
lower in 1967, and so on until it was 6.6 deaths per 1000 births lower in 1975.

The multiplication of these declines in the PNMR by the annual number of black births in the rural South implies that roughly 4,700 additional survived from age 1 month to age 1 year during the years 1965-1975 and 25,300 infants from 1965-2002. ${ }^{44}$ Alternatively, it may be reasonable to ascribe the entire post-1965 trend break in post-neonatal mortality (i.e. post-neonatal deaths from all causes) to the mandated integration. In this case, these numbers would rise to 7,100 and 38,600 , respectively. ${ }^{45}$ These calculations suggest that the mandated integration of hospitals in the rural South accounted for $16 \%$ (based on preventable causes only) or $25 \%$ (based on all post-neonatal fatalities) of the national 7.5 per 1,000 decline in the national black PNMR between 1965 and 1975.

An alternative means to assess the magnitude of these gains is to ask how much blacks in the rural South would have been willing to pay (WTP) for these reductions in infant mortality. ${ }^{46}$ To develop an estimate of WTP, we use Ashenfelter and Greenstone's (2004) upper bound estimate of \$1.9 million $(2005 \$)$ as the value of a statistical life (VSL). ${ }^{47}$ With this value and a $3 \%$ discount rate, we estimate that blacks in the rural South in 1965 had a WTP for the reduction in infant mortality that occurred between 1965 and 1975 of \$7.3 billion (for preventable cause post-neonatal fatalities) and \$11.1 billion (for all cause post-neonatal mortality). Among all black residents of the rural South, the WTP per capita was $\$ 1,400$ and $\$ 2,100$ (for preventable and all-cause PNMR reductions, respectively). If we keep the reduction in black post-neonatal deaths constant at the 1975 reduction for the 1975-2002 period, there are additional gains of $\$ 20.1$ billion (preventable causes) and $\$ 30.8$ (all post-neonatal causes) for the 1975-

\footnotetext{
${ }^{44}$ For the years after 1975, we hold the PNMR reduction constant at the 1975 level of 6.6. per 1,000 births.

${ }^{45}$ Alternative assumptions would cause these numbers to be even larger. For example, it may be appropriate to use the estimates from Table 2 that rely on the 1955-65 period (rather than the 1960-65 period as in Table 3 ) to estimate the pre-1966 trend. The trend break estimates in Table 3 are larger because the black post-neonatal mortality rate worsened from 1955-1960, which is consistent with white resistance to the burgeoning Civil Rights movement (Garrow 1986 and Caro 2002). Additionally, it might be appropriate to add the reduction in the black-white postneonatal mortality rate in the rural South, although this effect isn't statistically significant. There were also pre-1965 access disparities in the urban South so some may consider it appropriate to add the post-1965 trend break in postneonatal mortality. This argument is undermined by the finding of no trend break in preventable causes (see column (2c) of Table 3). Our view is that the evidence in favor of attributing any IMR declines in other regions is weak due to the absence of evidence on ex-ante access disparities.

${ }^{46}$ Obviously, this approach assumes the WTP was positive only for blacks in the South and to the extent this is incorrect, will yield conservative estimates.

${ }^{47}$ This is at the low end of the range of estimates of the VSL, but we think it is appropriate to be conservative for several reasons including that this estimate comes from more than two decades after the Civil Rights Act, blacks in the rural South had relatively low incomes, and WTP to prevent an infant death may be lower than for an adult death (Murphy and Topel 2006).
} 
2002 period (an additional per capita gain of $\$ 3,900$ and $\$ 5,900$ ).

These measures of WTP for the improvements in infant mortality likely underestimate (potentially substantially) a measure of WTP for hospital integration. Integration presumably reduced mortality rates among other age groups and reduced morbidities across all ages. Further, the practice of segregation may have imposed additional costs on hospitals through duplication of services. ${ }^{48}$ On the other side of the ledger, the expanded supply of health care presumably had a social cost, and a full welfare analysis would account for these added costs. It may also be appropriate to subtract the administrative costs incurred in the achievement of integration, although they are likely to be a relatively small one-time cost.

\section{Conclusions}

Passage of Title VI of the Civil Rights Act marked a reversal of federal policy with respect to race. In prohibiting discrimination and segregation in all institutions receiving federal funds, and through its vigorous enforcement by the Johnson Administration, black access to hospitals in the rural South was quickly and dramatically expanded, with large benefits in terms of infant lives saved. We conclude that the benefits of 1960s Civil Rights legislation extended beyond the labor market and therefore are substantially larger than has been recognized previously.

These findings are relevant for current discussions regarding the efficient allocation of public resources in developing countries. More than a third of children in low-income countries do not receive treatment for acute respiratory infections and only half receive proper care for diarrhea (Jha et al., 2002:2037). This paper illustrates that health treatments are sought out when made available and can have large and immediate benefits.

\footnotetext{
${ }^{48}$ Desegregation "requires less personnel and contributes to the efficiency of the hospital if there are not two waiting rooms, two maternity units, and two intensive care units -- one for Negroes and one for whites." (Nash 1968:249). Similarly, Seham noted that such duplication was "bad business." (Seham 1964:943).
} 


\section{REFERENCES}

\section{$\underline{\text { ACADEMIC }}$}

Almond, Douglas, Kenneth Chay, Hilary Hoynes, and Diane Whitmore Schanzanbach. "The Great Society, Food Stamps, and Infant Health." Manuscript, UC Davis: 2006 a.

Almond, Douglas, Kenneth Chay, Michael Greenstone, Stacy Sneeringer, and Melissa Thomasson. "The 1946 Hospital Construction Act and Infant Mortality in the United States after World War II." Manuscript, UC Berkeley: 2006b.

Ashenfelter, Orley and Michael Greenstone. "Using Mandated Speed Limits to Measure the Value of a Statistical Life." Journal of Political Economy, February 2004, 112(1, Pt. 2), pp. S226-S267.

Bond, Horace Mann. Negro Education in Alabama: A Study in Cotton and Steel. New York: Associate Publishers, 1939.

Caro, Robert A. Master of the Senate: The Years of Lyndon Johnson. New York: Knopf, 2002.

Chabot, André. "Improved Infant Mortality Rates in a Population Served by a Comprehensive Neighborhood Health Program." Pediatrics, June 1971, 47(6), pp. 989-94.

Chay, Kenneth Y. "Evaluating the Impact of the 1964 Civil Rights Act on the Economic Status of Black Men Using Censored Longitudinal Earnings Data." Mimeo, Princeton University, October 1995.

Chay, Kenneth Y. "The Impact of Federal Civil Rights Policy on Black Economic Progress: Evidence from the Equal Employment Opportunity Act of 1972." Industrial and Relations Review, July 1998, 51(4), pp. 608-632.

Chay, Kenneth Y. and Michael Greenstone. "The Convergence in Black/White Infant Mortality Rates during the 1960s." American Economic Review Papers and Proceedings, May 2000, 90(2), pp. 326 332.

Davis, Karen and Schoen, Cathy. Health and the War on Poverty: A Ten-Year Appraisal. Washington, DC: The Brookings lnstitution, 1978.

Donohue, John J. and Heckman, James J. "Continuous Versus Episodic Change: The lmpact of Affirmative Action and Civil Rights Policy on the Economic Status of Blacks." Journal of Economic Literature, December 1991, 29(4), pp. 1603-44.

Emery, J.L. "Unexpected Death in lnfancy" in Recent Advances in Pediatrics David Hull, editor, New York: Churchill Livingstone, 1976.

Garrow, David J. Bearing the Cross: Martin Luther King Jr., and the Southern Christian Leadership Conference. New York: Vintage, 1988.

Gold, Edwin M., Stone, M.L., and Rich, Herbert. "Total Maternal and Infant Care: An Evaluation." American Journal of Public Health, October 1969, $\underline{59}$ (10), pp. 1851-6.

Goldman, Fred and Grossman, Michael. "The lmpact of Public Health Policy: The Case of Community Health Centers." Eastern Economic Journal, January-March 1988, XIV(1), pp. 63-72. 
Grossman, Michael and Jacobowitz, Steven. "Variations in Infant Mortality Rates among Counties of the United States: The Roles of Public Policies and Programs." Demography, November 1981, 18(4), pp. 695-713.

Heckman, James J. and Brook Payner. "Determining the Impact of Federal Antidiscrimination Policy on the Economic Status of Blacks: A Study of South Carolina." American Economic Review, March $1989, \underline{79}(1)$, pp. 138-77.

Murphy, Kevin M. and Robert H. Topel. "The Value of Health and Longevity." Joumal of Political Economy, October 2006, 114(5), pp. 871-904.

Jha, Prabhat Anne Mills, Kara Hanson, Lilani Kumaranayake, Lesong Conteh, Christoph Kurowski, Son Nam Nguyen, Valeria Oliveira Cruz, Kent Ranson, Lara M. E. Vaz, Shengchao Yu, Oliver Morton, Jeffrey D. Sachs. "Improving the Health of the Global Poor." Science, March 15, 2002, 295, pp.2036-2039.

Nash, Robert M. "Compliance of Hospitals and Health Agencies with Title VI of the Civil Rights Act." American Journal of Public Health, February 1968, 58 (2), pp. 246-251. (presented November 3, 1966 at the American Public Health Association Annual Meeting in San Francisco, CA.)

Nelson, Waldo E., editor Textbook of Pediatrics. Philadelphia: W.B. Saunders Company, 1964.

Peoples, Mary Dennis, and Siegel, Earl. "Measuring the Impact of Programs for Mothers and Infants on Prenatal Care and Low Birth Weight: The Value of Refined Analysis." Medical Care, June 1983, 21(6), pp. 586-605.

Quadagno, Jill. "How Medicare Promoted Racial Integration in the Health Care System: Explaining Variation in Social Movement Outcomes." Mimeo, Florida State University, 1999.

Reynolds, Preston P. "Hospitals and Civil Rights, 1945-1963: The Case of Simkins v Moses H. Cone Memorial Hospital." Annals of Internal Medicine, June 1997, 126, pp. 898-906.

Seham, Max. "Discrimination Against Negroes in Hospitals." The New England Journal of Medicine, October 1964, 271(18), pp. 940-943.

Shapiro, Sam, Schlesinger, Edward R., and Nesbitt Jr., Robert E. L. Infant, Perinatal, Maternal, and Childhood Mortality in the United States. Cambridge: Harvard University Press, 1968.

Smith, David Barton. Health Care Divided: Race and Healing a Nation. Ann Arbor: University of Michigan Press, 1999.

Smith, David Barton. "Racial and Ethnic Disparities and the Unfinished Civil Rights Agenda." Health Affairs, Mar/Apr 2005, 24 (2), pp. 317-325.

Sokol, Robert J., Woolf, Ralph B., Rosen, Mortimer G., and Weingarten, Kenneth. "Risk, Antepartum Care, and Outcome: Impact of a Maternity and Infant Care Project." Obstetrics and Gynecology, August 1980, 56(2), pp. 150-6.

\section{GOVERNMENT}

Javits, Jacob Koppel. “Excerpts from Sen. Javits' Report to the Senate.” Journal of the National Medical 
Association, January 1962: pp. 120-122.

Mississippi Advisory Committee to the United States Commission On Civil Rights. Report on Mississippi. Washington, DC: General Services Administration, 1963

United States Commission on Civil Rights. Civil Rights '63. Washington, DC: U.S. Government Printing Office, 1963.

United States Commission on Civil Rights. Title V1...One Year After. Washington, DC: United States Commission on Civil Rights, 1966.

United States Court of Appeals Fourth Circuit: Court Opinions. Simkins v Moses H. Cone Memorial Hospital. Lexis 3837, November 1, 1963.

U.S. Department of Health, Education, and Welfare: Memo from Gladys Harrison to Parke M. Banta. "Hospital survey and construction-Nondiscrimination requirements under present statute-Possible modification of regulations." January 31, 1956.

U.S. Department of Health, Education, and Welfare: Memo from Alanson W. Wilcox to Dr. Jack C. Haldeman. "Letter of February 4 from Senator Harrison A. Williams Jr." February 12, 1963.

U.S. Department of Health, Education, and Welfare: Memo from Donald J. Dawidoff. "Conduct Required Under State Statutes Which Is Inconsistent with the Nondiscrimination Assurance in the Hill-Burton, Mental Retardation Facilities and Community Mental Health Centers Construction Programs.” June 26, 1964.

U.S. Department of Health, Education, and Welfare. Hill-Burton Program 1946-1966. Washington, DC: U.S. Government Printing Office, 1966.

U.S. Department of Health and Human Services. Aid to Families with Dependent Children: The Baseline. Washington, DC: Office of the Assistant Secretary for Planning and Evaluation, 1998.

U.S. Department of Health and Human Services. Celebrating 65 Years of Title V: The Maternal and Child Health Program. Rockville, MD: Maternal and Child Health Bureau, 2001. 


\begin{tabular}{|c|c|c|c|}
\hline & (1) & $(2)$ & $(3)$ \\
\hline \multicolumn{4}{|c|}{ A. Fraction of Births Occurring in a Hospital with Physician Present, 1955-1965 } \\
\hline Urban Rustbelt & $\frac{\text { Black }}{97.0}$ & $\frac{\text { White }}{99.3}$ & $\frac{\text { Black-white Difference }}{2.4}$ \\
\hline Urban Elsewhere & 98.4 & 99.4 & 1.0 \\
\hline Urban South & 92.8 & 98.4 & 5.6 \\
\hline Rural South & 60.1 & 95.9 & 35.7 \\
\hline Mississippi & 47.6 & 98.1 & 50.5 \\
\hline \multicolumn{4}{|c|}{ B. Allocated Hospital Beds Per 1,000 Births by Race in Mississippi, 1960-1964 } \\
\hline Entire State & $\frac{\text { Black beds }}{158.2}$ & $\frac{\text { White beds }}{353.7}$ & $\frac{\text { Black-white ratio }}{.447}$ \\
\hline Counties Where $>2 / 3$ of Births are to Blacks & 40.4 & 229.1 & .176 \\
\hline Counties Where $<2 / 3$ of Births are to Blacks & 246.5 & 374.8 & .658 \\
\hline
\end{tabular}

Notes: There were 25 counties in Mississippi where the fraction of births to blacks exceeded 2/3 during the years 1959-1963.
The remaining 57 counties are assigned to the less than $2 / 3$ category. The data sources are described in the Data Appendix. 
Table 2: Trends in Black and White Infant Mortality Rates in United States, 1955-1975

\begin{tabular}{|c|c|c|c|c|c|c|}
\hline & \multicolumn{6}{|c|}{ Infant death (per 1,000 live births) } \\
\hline & \multicolumn{3}{|c|}{ Post-neonatal mortality } & \multicolumn{3}{|c|}{ Neonatal mortality } \\
\hline & Black & White & Black-white & Black & White & Black-white \\
\hline & (1a) & (1b) & (1c) & $(2 a)$ & $(2 \mathrm{~b})$ & $(2 \mathrm{c})$ \\
\hline \multicolumn{7}{|l|}{ A. Rural South } \\
\hline $1955-1965$ trend & $\begin{array}{c}0.086 \\
(0.088)\end{array}$ & $\begin{array}{l}-0.133^{* * *} \\
(0.038)\end{array}$ & $0.180^{* *}$ & $\begin{array}{l}-0.104 \\
(0.140)\end{array}$ & $-0.150^{* * *}$ & 0.037 \\
\hline \multirow{2}{*}{ Post-1965 trend break } & $-1.546^{* * *}$ & $-0.138^{\cdots}$ & $-1.407^{* * *}$ & $-0.679^{* *}$ & $-0.322^{* * *}$ & -0.355 \\
\hline & $(0.149)$ & $(0.025)$ & $(0.144)$ & $(0.232)$ & $(0.043)$ & $(0.223)$ \\
\hline R-squared & 0.853 & 0.803 & 0.820 & 0.718 & 0.824 & 0.438 \\
\hline 1955-65 Mean Dep Var & 21.8 & 7.3 & 15.2 & 26.2 & 18.1 & 8.2 \\
\hline \multicolumn{7}{|l|}{ B. Urban South } \\
\hline \multirow[t]{2}{*}{$1955-1965$ trend } & $-0.092^{* *}$ & $-0.066^{* *}$ & -0.050 & $-0.273^{* * *}$ & $-0.188^{* * *}$ & -0.059 \\
\hline & $(0.041)$ & $(0.025)$ & $(0.033)$ & $(0.051)$ & $(0.028)$ & $(0.045)$ \\
\hline \multirow[t]{2}{*}{ Post-1965 trend break } & $-0.678^{* * *}$ & $-0.087^{* * *}$ & $-0.571^{* * *}$ & $-0.650^{* * *}$ & $-0.436^{* * *}$ & $-0.273^{* * *}$ \\
\hline & $(0.087)$ & $(0.019)$ & $(0.078)$ & $(0.079)$ & $(0.061)$ & $(0.070)$ \\
\hline R-squared & 0.800 & 0.705 & 0.731 & 0.769 & 0.878 & 0.449 \\
\hline 1955-65 Mean Dep Var & 13.8 & 5.2 & 8.8 & 27.3 & 17.6 & 9.5 \\
\hline \multicolumn{7}{|l|}{ C. Urban Rustbelt } \\
\hline \multirow[t]{2}{*}{$1955-1965$ trend } & -0.001 & $-0.046^{* *}$ & 0.048 & -0.146 & $-0.138^{* *}$ & -0.019 \\
\hline & $(0.040)$ & $(0.011)$ & $(0.033)$ & $(0.128)$ & $(0.047)$ & $(0.102)$ \\
\hline \multirow[t]{2}{*}{ Post-1965 trend break } & $-0.368^{* *}$ & $-0.091^{* *}$ & $-0.279^{* *}$ & $-0.881^{* * *}$ & $-0.396^{* * *}$ & $-0.477^{* *}$ \\
\hline & $(0.084)$ & $(0.023)$ & $(0.071)$ & $(0.166)$ & $(0.042)$ & $(0.155)$ \\
\hline R-squared & 0.768 & 0.876 & 0.649 & 0.820 & 0.944 & 0.562 \\
\hline 1955-65 Mean Dep Var & 11.0 & 5.0 & 6.0 & 29.0 & 16.7 & 12.4 \\
\hline \multicolumn{7}{|l|}{ D. Urban Elsewhere } \\
\hline \multirow[t]{2}{*}{$1955-1965$ trend } & -0.099 & $-0.045^{* * *}$ & -0.052 & $-0.305^{* * *}$ & $-0.209^{* * *}$ & -0.106 \\
\hline & $(0.061)$ & $(0.013)$ & $(0.052)$ & $(0.090)$ & $(0.024)$ & $(0.069)$ \\
\hline \multirow{2}{*}{ Post-1965 trend break } & $-0.257^{* * *}$ & $-0.119^{* * *}$ & $-0.152^{* * * *}$ & $-0.745^{* * *}$ & $-0.404^{* * * *}$ & $-0.321^{*}$ \\
\hline & $(0.053)$ & $(0.015)$ & $(0.051)$ & $(0.156)$ & $(0.026)$ & $(0.167)$ \\
\hline R-squared & 0.624 & 0.744 & 0.590 & 0.823 & 0.891 & 0.682 \\
\hline 1955-65 Mean Dep Var & 10.1 & 5.2 & 4.9 & 25.7 & 16.7 & 9.0 \\
\hline \multicolumn{7}{|l|}{ E. Mississippi } \\
\hline \multirow[t]{2}{*}{ 1955-1965 trend } & $0.291^{* *}$ & $-0.073^{*}$ & $0.356^{* * *}$ & $0.517^{* * *}$ & -0.139 & $0.666^{* * *}$ \\
\hline & $(0.101)$ & $(0.037)$ & $(0.094)$ & $(0.099)$ & $(0.090)$ & $(0.147)$ \\
\hline \multirow[t]{2}{*}{ Post- 1965 trend break } & $-1.954 * * *$ & -0.130 & $-1.812 * * *$ & $-1.647 * * *$ & $-0.495^{* * *}$ & $-1.175^{* * * *}$ \\
\hline & $(0.195)$ & $(0.078)$ & $(0.177)$ & $(0.186)$ & $(0.166)$ & $(0.290)$ \\
\hline R-squared & 0.92 & 0.73 & 0.92 & 0.85 & 0.82 & 0.55 \\
\hline 1955-65 Mean Dep Var & 23.1 & 5.6 & 17.4 & 28.1 & 19.4 & 8.7 \\
\hline \multicolumn{7}{|c|}{$\begin{array}{l}\text { Notes: Estimated standard errors arc shown in parentheses and are corrected for heteroskedasticity and clustering at the state- } \\
\text { level. All specifications include state fixed effects. The "Elsewhere" states are those outside of the South and Rust Belt. The } \\
\text { sample sizes of the regressions represent the number of state-years. The regressions in the "Black" and "White" columns are } \\
\text { weighted by the number of nonwhite and white births in the nonmetropolitan or metropolitan counties of each state and year. } \\
\text { The regressions in the "Black-White" column are weighted by the number of nonwhite births. The sample sizes for all } \\
\text { regressions from the Rural South, Urban South, Urban Rustbelt, Urban Elsewhere, and Mississippi are 336, 357, 105, 487, and } \\
\text { 21, respeclively. }\end{array}$} \\
\hline
\end{tabular}


Table 3: Trends in Black and White Post-neonatal Mortality Rates Due to Pneumonia, Influenza, and Gastroenteritis, by Region, 1960-1975

\begin{tabular}{|c|c|c|c|c|}
\hline & \multirow{2}{*}{ 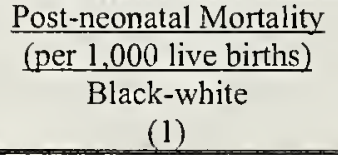 } & \multicolumn{3}{|c|}{$\frac{\text { Post-neonatal Mortality (per } 1,000 \text { live births) Due to }}{\text { Pneumonia, Influenza, \& Gastroenteritis }}$} \\
\hline & & $\begin{array}{c}\begin{array}{c}\text { Black } \\
(2 a)\end{array} \\
\end{array}$ & $\begin{array}{l}\text { White } \\
(2 \mathrm{~b})\end{array}$ & $\begin{array}{l}\text { Black-white } \\
(2 \mathrm{c}) \\
\end{array}$ \\
\hline \multicolumn{5}{|l|}{ A. Rural South } \\
\hline 1960-1965 trend & $\begin{array}{c}-0.132 \\
(0.079)\end{array}$ & $\begin{array}{l}-0.210^{* *} \\
(0.086)\end{array}$ & $\begin{array}{l}-0.103 * * * \\
(0.027)\end{array}$ & $\begin{array}{l}-0.115 \\
(0.084)\end{array}$ \\
\hline Post-1965 trend break & $\begin{array}{c}-1.005^{* * *} \\
(0.134)\end{array}$ & $\begin{array}{l}-0.705^{* * *} \\
(0.125)\end{array}$ & $\begin{array}{c}-0.076^{* *} \\
(0.027)\end{array}$ & $\begin{array}{c}-0.659 * * * \\
(0.124)\end{array}$ \\
\hline R-squared & 0.883 & 0.909 & 0.811 & 0.881 \\
\hline $\begin{array}{l}\text { 1960-65 Mean Dep Var } \\
\text { B. Urban South }\end{array}$ & 15.9 & 11.3 & 2.6 & 9.1 \\
\hline $1960-1965$ trend & $\begin{array}{c}-0.320 * * * \\
(0.077)\end{array}$ & $\begin{array}{c}-0.359 * * * \\
(0.073)\end{array}$ & $\begin{array}{l}-0.060^{*} \\
(0.030)\end{array}$ & $\begin{array}{c}-0.315^{* * *} \\
(0.078)\end{array}$ \\
\hline Post-1965 trend break & $\begin{array}{c}-0.234^{* *} \\
(0.090)\end{array}$ & $\begin{array}{l}-0.036 \\
(0.075)\end{array}$ & $\begin{array}{c}-0.023 \\
(0.028)\end{array}$ & $\begin{array}{l}-0.002 \\
(0.075)\end{array}$ \\
\hline R-squared & 0.750 & 0.819 & 0.803 & 0.776 \\
\hline $\begin{array}{l}\text { 1960-65 Mean Dep Var } \\
\text { C. Urban Rustbelt }\end{array}$ & 8.9 & 5.6 & 1.4 & 4.4 \\
\hline 1960-1965 trend & $\begin{array}{c}0.069 \\
(0.072)\end{array}$ & $\begin{array}{c}-0.220^{* *} \\
(0.064)\end{array}$ & $\begin{array}{c}-0.062^{* *} \\
(0.015)\end{array}$ & $\begin{array}{l}-0.155 \\
(0.056)\end{array}$ \\
\hline Post-1965 trend break & $\begin{array}{c}-0.300^{* * *} \\
(0.063)\end{array}$ & $\begin{array}{l}-0.205 \\
(0.193)\end{array}$ & $\begin{array}{l}-0.048^{*} \\
(0.019)\end{array}$ & $\begin{array}{l}-0.151 \\
(0.173)\end{array}$ \\
\hline R-squared & 0.847 & 0.763 & 0.852 & 0.721 \\
\hline $\begin{array}{l}\text { 1960-65 Mean Dep Var } \\
\text { D. Urban Elsewhere }\end{array}$ & 6.1 & 5.4 & 1.6 & 3.7 \\
\hline $1960-1965$ trend & $\begin{array}{c}0.078 \\
(0.036)\end{array}$ & $\begin{array}{l}0.095^{*} \\
(0.051)\end{array}$ & $\begin{array}{l}-0.027 \\
(0.031)\end{array}$ & $\begin{array}{c}0.110^{* * *} \\
(0.039)\end{array}$ \\
\hline Post-1965 trend break & $\begin{array}{c}-0.301+* * \\
(0.087)\end{array}$ & $\begin{array}{c}-0.452 * * * \\
(0.044)\end{array}$ & $\begin{array}{c}-0.101^{* *} \\
(0.039)\end{array}$ & $\begin{array}{c}-0.338^{* * *} \\
(0.069)\end{array}$ \\
\hline R-squared & 0.585 & 0.666 & 0.781 & 0.591 \\
\hline $\begin{array}{l}\text { 1960-65 Mean Dep Var } \\
\text { E. Mississippi }\end{array}$ & 4.5 & 4.3 & 1.8 & 2.5 \\
\hline $1955-1965$ trend & $\begin{array}{c}0.092 \\
(0.218)\end{array}$ & $\begin{array}{l}-0.001 \\
(0.176)\end{array}$ & $\begin{array}{l}-0.066^{* *} \\
(0.024)\end{array}$ & $\begin{array}{c}0.066 \\
(0.175)\end{array}$ \\
\hline Post-1965 trend break & $\begin{array}{c}-1.485^{* * *} \\
(0.315)\end{array}$ & $\begin{array}{c}-0.935^{* * *} \\
(0.249)\end{array}$ & $\begin{array}{c}-0.005 \\
(0.038)\end{array}$ & $\begin{array}{c}-0.931 * * * \\
(0.251)\end{array}$ \\
\hline R-squared & 0.94 & 0.92 & 0.75 & 0.91 \\
\hline 1960-65 Mean Dep Var & 18.7 & 11.0 & 1.3 & 9.7 \\
\hline
\end{tabular}

Notes: Estimated standard errors are shown in parentheses and are corrected for heteroskedasticity and clustering at the statelevel. All specifications include state fixed effects. The "Elsewhere" states are those outside of the South and Rust Belt. The sample sizes of the regressions represent the number of state-years. The regressions in the "Black" and "White" columns are weighted by the number of nonwhite and white births in the nonmetropolitan or metropolitan counties of each state and year. The regressions in the "Black-White" column are weighted by the number of nonwhite births. The sample sizes for all regressions from the Rural South, Urban South, Urban Rustbelt, Urban Elsewhere, and Mississippi are 256, 272, 80, 388, and 16, respectively.

significant at 1-percent level, "“ significant at 5-percent level, " significant at 1-percent level 
Table 4: Event-Study Estimates of Impact of a Medicare Certified Hospital on County-Level Postneonatal Mortality Rates in Mississippi

\begin{tabular}{|c|c|c|c|c|c|c|}
\hline & \multicolumn{2}{|c|}{$\begin{array}{l}\text { Post-neonatal Fatalities } \\
\text { (per } 1,000 \text { births) }\end{array}$} & \multicolumn{2}{|c|}{$\begin{array}{c}\text { Post-neonatal } \\
\text { Preventable-Cause } \\
\text { Fatalities } \\
\text { (per } 1,000 \text { births) }\end{array}$} & \multicolumn{2}{|c|}{$\begin{array}{l}\text { Percent of Births in } \\
\text { Hospital With Doctor } \\
\text { Present }\end{array}$} \\
\hline & (1a) & $(\mathrm{lb})$ & $(2 \mathrm{a})$ & (2b) & (3a) & (3b) \\
\hline A. Blacks & & & & & & \\
\hline Pre-certify trend & $\begin{array}{c}0.010 \\
(0.198)\end{array}$ & & $\begin{array}{l}-0.121 \\
(0.173)\end{array}$ & & $\begin{array}{c}2.085^{* * *} * \\
(0.251)\end{array}$ & \\
\hline Post-certify effects & & & & & & \\
\hline 1 year after & $\begin{array}{c}-5.739 * * * \\
(1.356)\end{array}$ & $\begin{array}{c}-5.837^{* * *} \\
(1.459)\end{array}$ & $\begin{array}{l}-2.913 * * * \\
(0.984)\end{array}$ & $\begin{array}{c}-2.599 * * * \\
(0.962)\end{array}$ & $\begin{array}{c}6.032 * * * \\
(0.872)\end{array}$ & $\begin{array}{c}5.139 * * * \\
(1.134)\end{array}$ \\
\hline 2 years after & $\begin{array}{c}-7.999 * * * \\
(1.367)\end{array}$ & $\begin{array}{c}-8.087 * * * \\
(1.504)\end{array}$ & $\begin{array}{l}-4.751^{* * * *} \\
(1.002)\end{array}$ & $\begin{array}{c}-4.402 * * * \\
(1.046)\end{array}$ & $\begin{array}{c}9.503 * * * \\
(1.435)\end{array}$ & $\begin{array}{c}8.419 * * * \\
(1.693)\end{array}$ \\
\hline 3 years after & $\begin{array}{c}-9.792 * * * \\
(1.543)\end{array}$ & $\begin{array}{c}-9.812^{* * *} \\
(1.831)\end{array}$ & $\begin{array}{l}-4.212^{* * *} \\
(1.169)\end{array}$ & $\begin{array}{c}-3.908^{* * *} \\
(1.307)\end{array}$ & $\begin{array}{c}12.961^{* * * *} \\
(2.007)\end{array}$ & $\begin{array}{l}11.653 * * * \\
(2.121)\end{array}$ \\
\hline 4 years after & $\begin{array}{l}-10.213^{* * * *} \\
(1.820)\end{array}$ & $\begin{array}{l}-10.297^{* * *} \\
(2.169)\end{array}$ & $\begin{array}{l}-4.990 * * * \\
(1.440)\end{array}$ & $\begin{array}{l}-4.642^{* * *} \\
(1.576)\end{array}$ & $\begin{array}{l}16.906^{* * *} \\
(2.401)\end{array}$ & $\begin{array}{c}15.082^{* * * *} \\
(2.597)\end{array}$ \\
\hline 5 years after & $\begin{array}{l}-11.470^{* * * *} \\
(2.055)\end{array}$ & $\begin{array}{l}-11.902 * * * \\
(2.461)\end{array}$ & $\begin{array}{c}-5.360^{* * * *} \\
(1.593)\end{array}$ & $\begin{array}{c}-4.959 * * * \\
(1.610)\end{array}$ & $\begin{array}{l}17.608 * * * \\
(2.855)\end{array}$ & $\begin{array}{c}15.748 * * * \\
(2.983)\end{array}$ \\
\hline 6 years after & $\begin{array}{l}-12.551^{* * * *} \\
(2.189)\end{array}$ & $\begin{array}{l}-12.861^{* * *} \\
\quad(2.782)\end{array}$ & $\begin{array}{l}-5.776^{* * *} \\
(1.827)\end{array}$ & $\begin{array}{l}-5.198^{* * *} \\
(1.955)\end{array}$ & $\begin{array}{c}18.886^{* * * *} \\
(3.233)\end{array}$ & $\begin{array}{c}16.046^{* * *} \\
(3.393)\end{array}$ \\
\hline R-squared & 0.20 & 0.42 & 0.16 & 0.43 & 0.37 & 0.96 \\
\hline B. Whites & & & & & & \\
\hline Pre-certify trend & $\begin{array}{l}-0.054 \\
(0.092)\end{array}$ & & $\begin{array}{c}-0.097^{* *} \\
(0.040)\end{array}$ & & $\begin{array}{l}0.078^{* *} \\
(0.030)\end{array}$ & \\
\hline Post-certify effects & & & & & & \\
\hline 1 year after & $\begin{array}{c}0.377 \\
(0.589)\end{array}$ & $\begin{array}{c}0.600 \\
(0.660)\end{array}$ & $\begin{array}{c}0.341 \\
(0.242)\end{array}$ & $\begin{array}{c}0.331 \\
(0.262)\end{array}$ & $\begin{array}{r}-0.039 \\
(0.125)\end{array}$ & $\begin{array}{l}-0.020 \\
(0.151)\end{array}$ \\
\hline 2 years after & $\begin{array}{l}-0.660 \\
(0.607)\end{array}$ & $\begin{array}{l}-0.302 \\
(0.691)\end{array}$ & $\begin{array}{c}0.409 \\
(0.287)\end{array}$ & $\begin{array}{c}0.395 \\
(0.333)\end{array}$ & $\begin{array}{c}0.032 \\
(0.130)\end{array}$ & $\begin{array}{c}0.046 \\
(0.155)\end{array}$ \\
\hline 3 years after & $\begin{array}{c}-1.030 \\
(0.667)\end{array}$ & $\begin{array}{l}-0.556 \\
(0.749)\end{array}$ & $\begin{array}{c}0.222 \\
(0.259)\end{array}$ & $\begin{array}{c}0.225 \\
(0.300)\end{array}$ & $\begin{array}{l}-0.191 \\
(0.152)\end{array}$ & $\begin{array}{l}-0.188 \\
(0.181)\end{array}$ \\
\hline 4 years after & $\begin{array}{c}-1.757^{* * *} \\
(0.716)\end{array}$ & $\begin{array}{c}-1.359 \\
(0.840)\end{array}$ & $\begin{array}{c}0.170 \\
(0.327)\end{array}$ & $\begin{array}{c}0.131 \\
(0.370)\end{array}$ & $\begin{array}{l}-0.015 \\
(0.172)\end{array}$ & $\begin{array}{c}0.000 \\
(0.195)\end{array}$ \\
\hline 5 years after & $\begin{array}{c}-1.520 * * \\
(0.729)\end{array}$ & $\begin{array}{c}-1.207 \\
(0.840)\end{array}$ & $\begin{array}{c}0.074 \\
(0.293)\end{array}$ & $\begin{array}{c}0.001 \\
(0.331)\end{array}$ & $\begin{array}{c}-0.168 \\
(0.201)\end{array}$ & $\begin{array}{c}-0.150 \\
(0.228)\end{array}$ \\
\hline 6 years after & $\begin{array}{c}-1.350 \\
(0.878)\end{array}$ & $\begin{array}{c}-1.082 \\
(1.020)\end{array}$ & $\begin{array}{c}0.067 \\
(0.355)\end{array}$ & $\begin{array}{c}-0.033 \\
(0.411)\end{array}$ & $\begin{array}{c}-0.104 \\
(0.224)\end{array}$ & $\begin{array}{c}-0.053 \\
(0.259)\end{array}$ \\
\hline R-squared & 0.04 & 0.24 & 0.03 & 0.25 & 0.05 & 0.52 \\
\hline County Fixed Effects & $\mathrm{N}$ & Y & $\mathrm{N}$ & Y & $\mathrm{N}$ & Y \\
\hline Event Time Trend & Y & Y & Y & $\mathrm{Y}$ & Y & $\mathrm{Y}$ \\
\hline County Time Trend & $\mathrm{N}$ & Y & $\mathrm{N}$ & Y & $N$ & Y \\
\hline Maternal characteristics & $N$ & Y & $\mathrm{N}$ & Y & $\mathrm{N}$ & Y \\
\hline Per-capita lnc \& Transfers & $\mathrm{N}$ & $\mathrm{Y}$ & $\mathrm{N}$ & $\mathrm{Y}$ & $\mathrm{N}$ & $\mathrm{Y}$ \\
\hline
\end{tabular}

Notes: Data are restricted to years no more than seven years before and six years after a county contained a hospital that received Medicare certification. See text for further details on the specification, especially how year of certification was determined for each county. Estimated standard errors are corrected for heteroskedasticity and clustering at the county level, Regressions are weighted by the number of births (by race) in each county and year. The sample size for all regressions is 1022 .

... 
Figure 1a: Trends in the Infant Mortality Rate by Race, 1950-1990

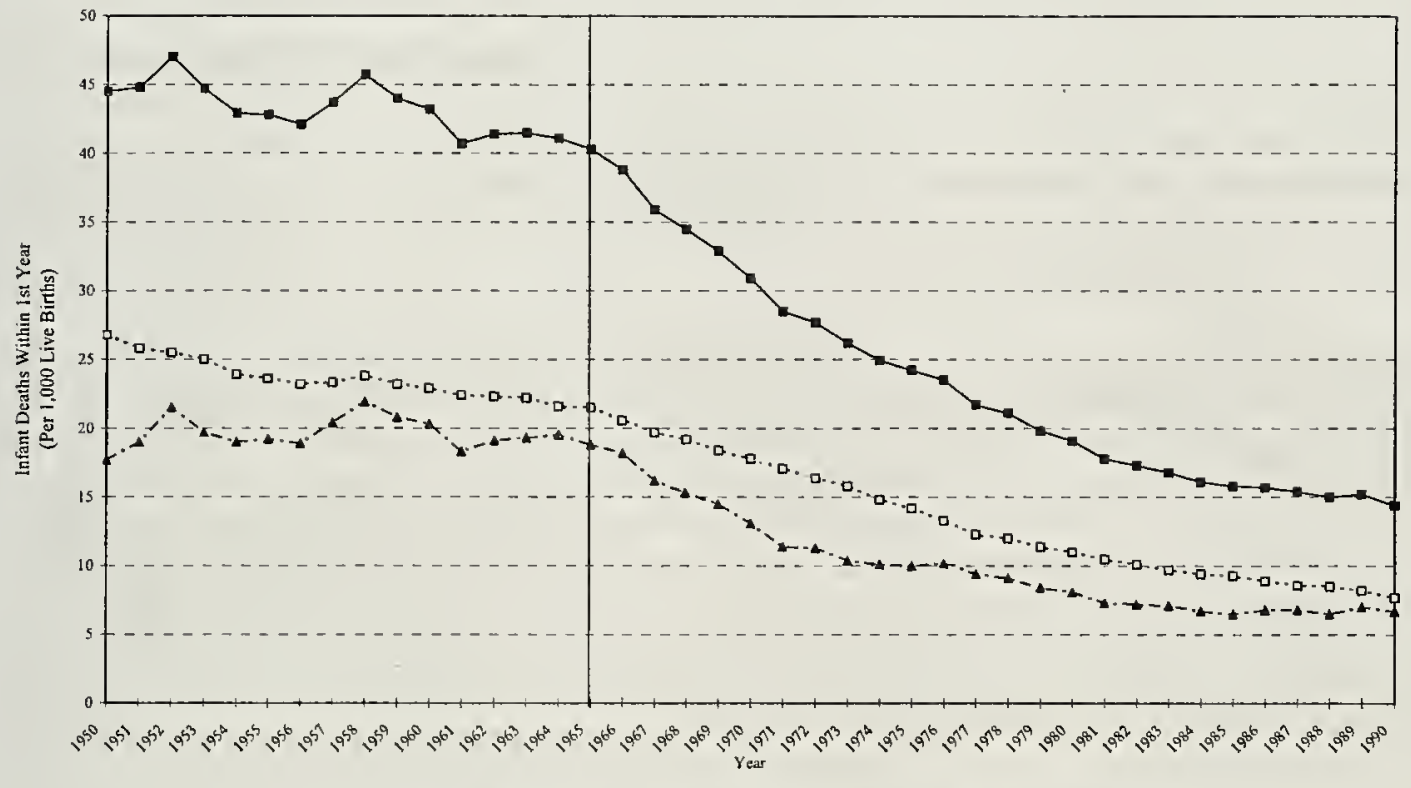

* a * White IMR $\quad \longrightarrow$ Non-White IMR $\quad--$ - Nonwhite IMR - White IMR Difference

Note: Alaska included in 1959 and Hawaii in 1960. The data were derived from various issues of the Vital Statistics of the United States.

Figure 1b: Number of Post-Neonatal lnfant Deaths due to Diarrhea and Pneumonia by Race in Mississippi, 1955-1975

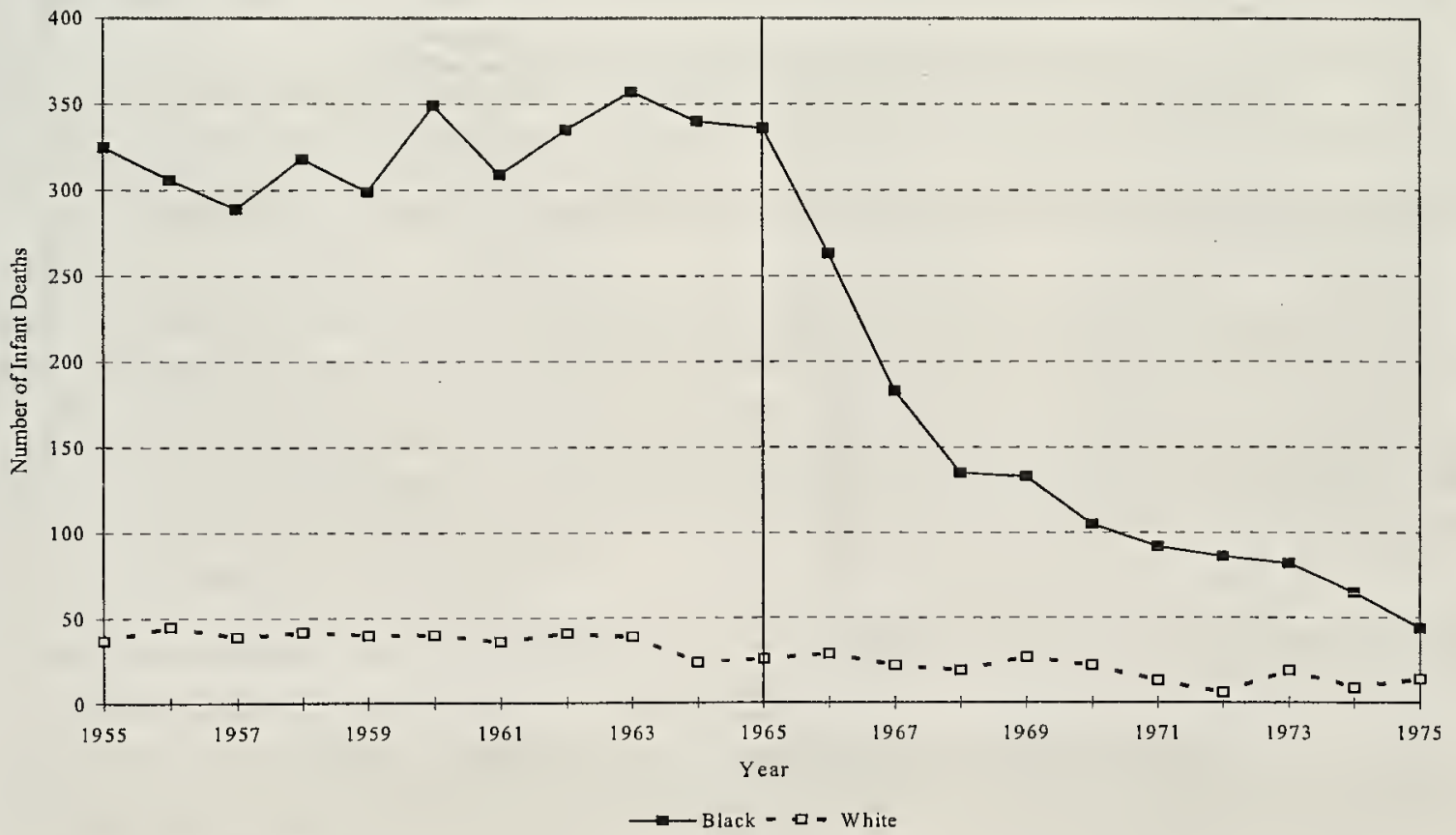


Figure 2: Black-White Difference in Infant Mortality by Region, 1955-1975

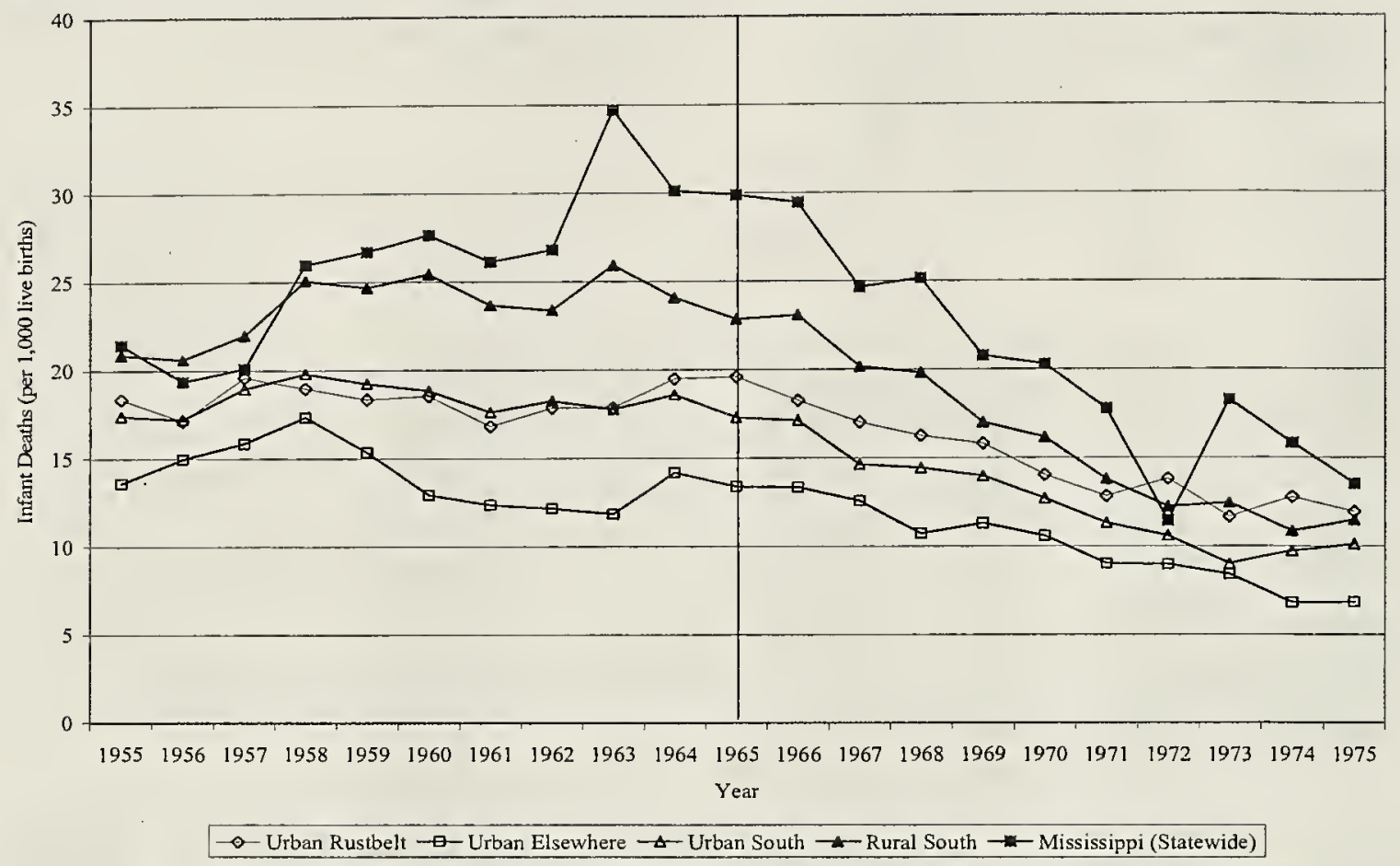

Figure 3: Black-White Difference in Postneonatal Mortality Rates by Time to Medicare Certification of Hospital in County of Residence.

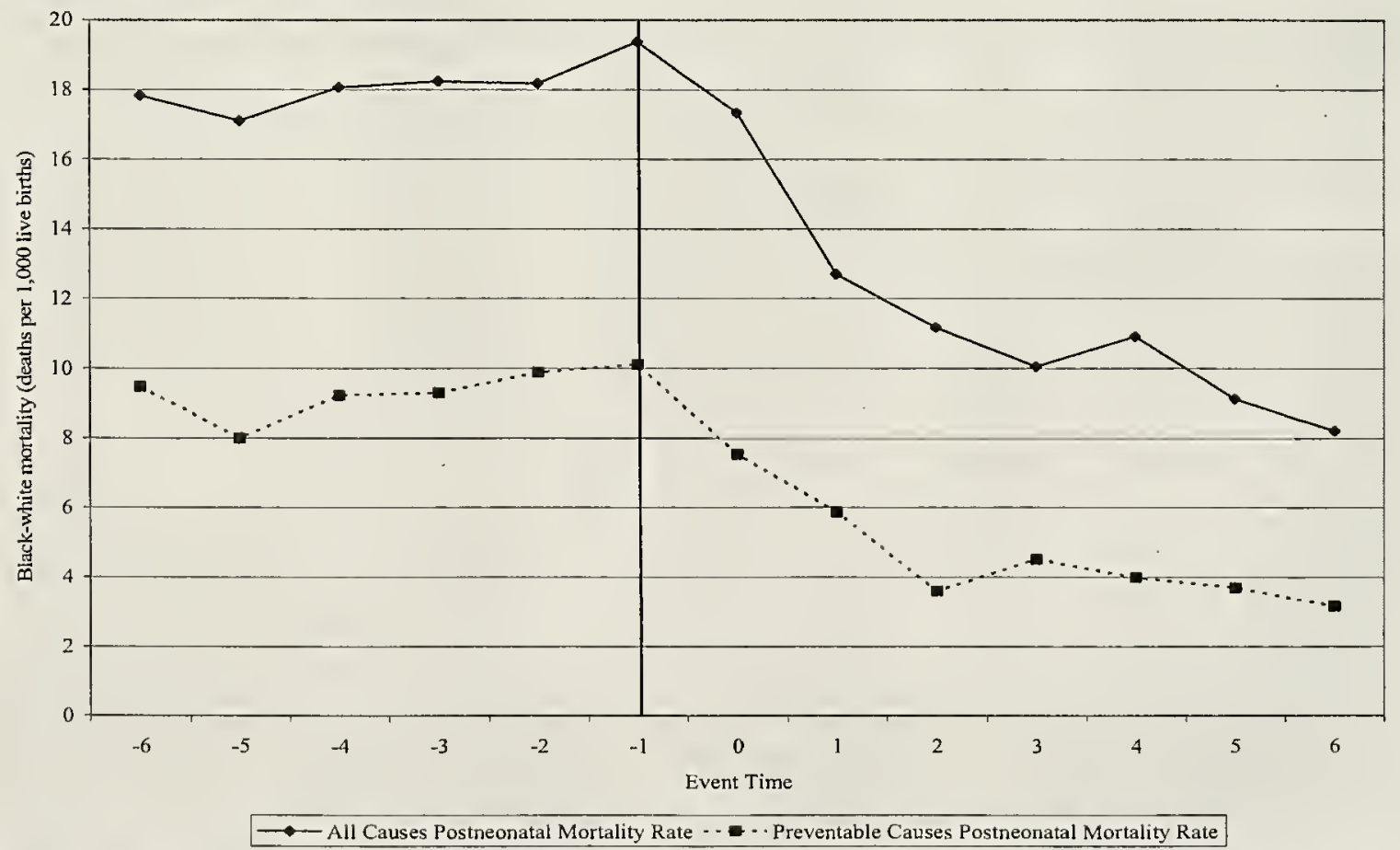

Notes: The figure plots the parameters associated with the event time indicators from the estimation of versions of equation (2). See the text for further details. 


\section{DATA APPENDIX}

\section{Natality and Mortality Data by Region}

As described in Section III.A, 1955-1975 aggregate data on births and (all cause) mortality was handentered from print publications of the Vital Statistics of the United States. We collected these annual series for rural and urban areas of each state, separately for whites and non-whites, entering each series twice to check for consistency.

Beginning in 1959, mortality microdata are available that provide detailed information on the specific cause of death (in addition to the information reported in the Vital Statistics of the United States volumes). We do not make use of the 1959 mortality microdata because the definition of urban versus rural counties differs from that available in Vital Statistics of the United States (for 1959 alone). We therefore begin aur analysis of causes of death by region with 1960. For the 1960-1967 period, the mortality microdata have only recently been made available by NCHS (and have sometimes been referred to as the "unpublished" mortality microdata). Mortality Data for these years may not be as reliable as that for the subsequent 1968-1975 period. According to the NBER website: "Counts by selected causes and demographic groups seem to match up with [Vital Statistics of the United States], but because in some cases these files had to be reconstructed and pieced together from different sources-some were damaged or lost-we cannot at this time be certain as to their accuracy."

The coding system used to categorize causes of death changed in 1967 from the $7^{\text {th }}$ Revision of the International Classification of Diseases (ICD-7) to the $8^{\text {th }}$ Revision (ICD-8) in 1968. The National Center for Health Statistics published in 1993 a mapping of ICD Codes across successive revisions to the system for certain common causes of infant death:

\begin{tabular}{|l|l|l||}
\hline \hline CAUSE OF DEATH & $\begin{array}{l}\text { ICD-7 CODE } \\
(1958-1967)\end{array}$ & $\begin{array}{l}\text { ICD-8 CODE } \\
(1968-1978)\end{array}$ \\
\hline Pneumonia and Influenza & $480-483,490-493,763$ & $470-474,480-486$ \\
\hline $\begin{array}{l}\text { Certain Gastrointestinal } \\
\text { Disease }\end{array}$ & $\begin{array}{l}045-048,543,571,572, \\
764\end{array}$ & $\begin{array}{l}004,006-009,535,561, \\
563\end{array}$ \\
\hline
\end{tabular}

Source: NCHS (1993)

NCHS (1993) assessed the quality of the mapping by computing "comparability ratios" that indicate how much the groupings changed over various ICD revisions. ${ }^{49}$ For both "Pneumonia and influenza" and "Certain Gastrointestinal Diseases" the comparability ratio between the $7^{\text {th }}$ and $8^{\text {th }}$ ICD systems is 1.075 . In addition to indicating relatively good correspondence across revisions, the change in systems would tend to understate the decrease in deaths attributable to these causes. According to NCHS (1993), a ratio of more than one usually "results from an increase in assignments of deaths to a cause in the Eighth revision as compared with the Seventh."

In addition to revisions to the ICD system over time, different studies may define cause of death

\footnotetext{
${ }^{49}$ To construct the comparability ratios between the $7^{\text {th }}$ and $8^{\text {th }}$ ICD, deaths in 1966 were coded according to both classification systems. The comparability ratio was computed as the number of deaths coded as a given cause using the $8^{\text {th }}$ revision divided by the number of deaths using the $7^{\text {th }}$ revision.

${ }^{50}$ Comparability of Mortality Statistics, page 3.
} 
groupings differently. In particular, Shapiro et al. (1968) used a broader definition of pneumonia and influenza than NCHS (1993), including ICD-7 codes 484-489. The additional causes of death included in the Shapiro definition are very rare. In fact, no deaths were coded 484-489 with the ICD-7 system from 1962 to 1967 in Mississippi. For gastroenteritis, the Shapiro et al. (1968) definition is more restrictive, excluding dysentery. Dysentery is similar to the types of diarrhea that fall under gastroenteritis in NCHS (1993). Again, dysentery so defined is also quite rare, composing only about 5 percent of infant deaths due to "Gastritis, duodentis, etc." in Mississippi (1965).

\section{Natality and Mortality Data for Mississippi}

Natality microdata are not available nationally for births before 1968. While the Vital Statistics of the United States print volumes list some county-level natality information, including the number of births by race as well as the proportion of births occurring in hospital, information on maternal age and marital status by county (separately by race) are absent.

The event-study analysis of Section VI therefore makes use of data provided by the Mississippi State Department of Health (MSDH). For confidentiality reasons, the MSDH did not make the microdata available, but instead provided county-level aggregates. The MSDH natality data contain detailed information on all births in Mississippi from 1959-1970, including counts of births by race and year for each of Mississippi's 82 counties. County counts are broken down by mother's age (under 15, 15-19, 2029, 30-34, 35+) and marital status. In addition, we obtained from MSDH the number of births by both county of residence and county of occurrence (which we make use of in the assignment of Medicare certification dates below). We extend these county-level natality data to 1975 using the microdata natality detail files. ${ }^{51}$

County-level mortality data for the 1959-1970 period are available from both the MSDH as well as the national "unpublished" mortality microdata. The MSDH data split deaths by race, whether the death was in the neonatal versus post-neonatal period, and whether gastroenteritis or pneumonia was given as a cause (using the ICD (1993) groupings described above). Given the uncertainty noted above concerning the accuracy of the "unpublished" microdata, we use the MSDH-supplied data for deaths prior to 1971, and the "published" natality microdata for 1971 to 1975.

\section{Transfer Payments and Income in Mississippi}

Data on Transfer Payments at the county level were collected by the Bureau of Economic Analysis (BEA), Department of Commerce. BEA provided a microfiche of their Regional Economic Information System data from 1959 to 1968 . County-level breakdowns of government transfer payments for 1959 , 1962, and 1965-1968 were provided. Among the payment categories are:

- Food Stamp Payments

- Aid to Families with Dependent Children (AFDC)

- State Unemployment Insurance Compensation

- Medical Insurance Payments

- Payments to Nonprofit Institutions

In our event study analysis, we include the annual total dollar amount of transfer payments net of medical insurance payments divided by the number of births in the same year. It is fortunate that the period in which data coverage is best (1965-1968) contains the years of largest decreases in infant mortality in

\footnotetext{
${ }^{51}$ The correspondence between the MSDH national natality county counts for 1970 was excellent (r-square statistics of .997 for white and non-white births)
} 
Mississippi. For years, we make county-specific linear interpolations and extrapolations, so as not to lose observations. $^{52}$

Finally, per-capita income data by county for 1959, 1962, 1965-1969 were obtained from the 1972 Mississippi Statistical Abstract. For missing data years, we again created county-level linear interpolations and extrapolations.

\section{Data on Hospital Beds in Mississippi}

Data on the number of hospital beds by race were taken from the Mississippi Commission on Hospital Care's List of Mississippi Hospitals with License Status and Governing Bodies. Directories were obtained for 1953, 1960, 1962, 1963, 1964, 1965, 1966, 1968, 1971. However, the breakdown of beds by race is provided through 1964 only, when Title Vl made segregation in federally-funded institutions illegal.

\section{Assignment of Medicare Certification Dates}

Information on when hospitals were certified for participation in the Medicare program was obtained from the Journal of the American Hospital Association annual guides issues for 1955-1975. Medicare certification status was taken from the approval code section which indicates "Certified for participation in the Health Insurance for the Aged (Medicare) Program by the Department of Health, Education, and Welfare."

As not all Mississippi counties had hospitals within their borders, we used the certification status of hospitals in neighboring counties. Fortunately, as noted above, the natality data provided by MSDH contained counts of births both by occurrence and maternal residence, and we focus on the neighboring county that is the largest destination of black births, and use the Medicare certification dates for the "importing" county. These assignments are delineated in Appendix Table 1. For example, because Smith county had no hospitals, most births occurred in neighboring counties. For blacks, the vast majority of births occurred in Jones county, which shares a border with Smith to the southeast. We therefore ascribe the (early) Medicare certification of Jones county to Smith county residents. In addition, four counties (Claiborne, Rankin, Wayne, Covingion) that had hospitals within their borders had earlier certification date reassigned because a large share of black births took place in a neighboring county with earlier Medicare certification.

52 Specifically, we use the Stata command: by county: ipolate trans_perb year, gen(Transfers per birth) epolate 
Appendix Table 1: Medicare Certification Dates of Hospitals in Mississippi Counties and Neighboring Hospitals Supplying Access

\begin{tabular}{|c|c|c|c|}
\hline County name & $\begin{array}{c}\text { Hospital } \\
\text { Certification }\end{array}$ & $\begin{array}{c}\text { Assigned } \\
\text { Certification }\end{array}$ & $\begin{array}{l}\text { Explanation for assigned year of } \\
\text { Medicare Certification }\end{array}$ \\
\hline Alcorn & 1967 & 1967 & $\ldots$ \\
\hline Attala & 1967 & 1967 & -- \\
\hline Bolivar & 1967 & 1967 & -- \\
\hline Chickasaw & 1967 & 1967 & -- \\
\hline Choctaw & 1967 & 1967 & --- \\
\hline Coahoma & 1967 & 1967 & -- \\
\hline Copiah & 1967 & 1967 & --- \\
\hline Franklin & 1967 & 1967 & -- \\
\hline George & 1967 & 1967 & -- \\
\hline Grenada & 1967 & 1967 & --- \\
\hline Hancock & 1967 & 1967 & -- \\
\hline Harrison & 1967 & 1967 & -- \\
\hline Hinds & 1967 & 1967 & -- \\
\hline Jackson & 1967 & 1967 & --- \\
\hline Jasper & 1967 & 1967 & -- \\
\hline Jefferson Davis & 1967 & 1967 & $\ldots$ \\
\hline Jones & 1967 & 1967 & -- \\
\hline Lafayette & 1967 & 1967 & -- \\
\hline Lauderdale & 1967 & 1967 & -- \\
\hline Leake & 1967 & 1967 & -- \\
\hline Lee & 1967 & 1967 & -- \\
\hline Lincoln & 1967 & 1967 & --- \\
\hline Madison & 1967 & 1967 & --- \\
\hline Marshall & 1967 & 1967 & -- \\
\hline Monroe & 1967 & 1967 & --- \\
\hline Newton & 1967 & 1967 & --- \\
\hline Oktibbeha & 1967 & 1967 & -- \\
\hline Pike & 1967 & 1967 & - \\
\hline Pontotoc & 1967 & 1967 & - \\
\hline Prentiss & 1967 & 1967 & -- \\
\hline$S \cot t$ & 1967 & 1967 & -- \\
\hline Stone & 1967 & 1967 & --- \\
\hline Tallahatchie & 1967 & 1967 & -- \\
\hline Tippah & 1967 & 1967 & - \\
\hline Union & 1967 & 1967 & -- \\
\hline Warren & 1967 & 1967 & -- \\
\hline Winston & 1967 & 1967 & -- \\
\hline Yalobusha & 1967 & 1967 & 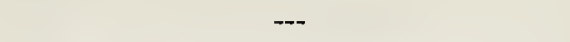 \\
\hline Claiborne & 1968 & 1967 & $46 \%$ of black births in Warren in 1967 \\
\hline $\begin{array}{l}\text { Rankin } \\
\text { (Jackson) }\end{array}$ & 1968 & 1967 & $82 \%$ of black births in Hinds in 1967 \\
\hline Wayne & 1969 & 1967 & $42 \%$ of black births (1967-68) in Jones \\
\hline Covington & 1970 & 1967 & $62 \%$ of black births in Jones in 1967 \\
\hline Neshoba & Unknown & 1967 & $37 \%$ black births (1966-68) in Lauderdale \\
\hline Calhoun & No hospital ${ }^{a}$ & 1967 & All 5 neighbor counties certified in 1967 \\
\hline Perry & No hospital $^{\mathrm{a}}$ & 1967 & $\begin{array}{l}55 \% \text { of black births (1966-68) in } 1967 \\
\text { certified counties }\end{array}$ \\
\hline Clarke & No hospital & 1967 & $46 \%$ black births (1966-68) in Lauderdale \\
\hline Smith & No hospital & 1967 & $74 \%$ of black births in Jones in 1967 \\
\hline
\end{tabular}

(continued on next page) 


\begin{tabular}{|c|c|c|c|}
\hline County name & $\begin{array}{c}\text { Hospital } \\
\text { Certification } \\
\end{array}$ & $\begin{array}{l}\text { Assigned } \\
\text { Certification } \\
\end{array}$ & $\begin{array}{l}\text { Explanation for assigned year of } \\
\text { Medicare Certification }\end{array}$ \\
\hline Clay & 1968 & 1968 & --- \\
\hline Forrest & 1968 & 1968 & -.. \\
\hline Lawrence & 1968 & 1968 & -.- \\
\hline Montgomery & 1968 & 1968 & --- \\
\hline Panola & 1968 & 1968 & -- \\
\hline Simpson & 1968 & 1968 & $\cdots$ \\
\hline Sunflower & 1968 & 1968 & --- \\
\hline Tunica & 1968 & 1968 & --- \\
\hline Washington & 1968 & 1968 & -- \\
\hline Kemper & No hospital & 1968 & $\begin{array}{l}\text { Black births in Lauderdale jumps to } 47 \% \\
\text { in } 1968-1969\end{array}$ \\
\hline Issaquena & No hospital & 1968 & $\begin{array}{l}\text { Combined black births in Warren and } \\
\text { Washington jumps to } 74 \% \text { in } 1968\end{array}$ \\
\hline Adams & 1969 & 1969 & --- \\
\hline Leflore & 1969 & 1969 & --- \\
\hline Marion & 1969 & 1969 & --- \\
\hline Holmes & 1969 & 1969 & -- \\
\hline Wilkinson & 1969 & 1969 & $\ldots$ \\
\hline Humphreys & 1970 & 1970 & --- \\
\hline Lowndes & 1970 & 1970 & --- \\
\hline Noxubee & 1970 & 1970 & -- \\
\hline Pearl River & 1970 & 1970 & --- \\
\hline Walthall & 1970 & 1970 & -.. \\
\hline Yazoo & 1970 & 1970 & -- \\
\hline Jefferson & $\begin{array}{c}1970 \\
\text { hospital }\end{array}$ & 1970 & -- \\
\hline Amite & No hospital & 1970 & Low $\%$ blacks born in early certifiers \\
\hline Benton & No hospital & 1970 & Low $\%$ blacks born in early certifiers \\
\hline Carroll & No hospital & 1970 & Low $\%$ blacks born in early certifiers \\
\hline De Soto & No hospital & 1970 & Low $\%$ blacks born in early certifiers \\
\hline Greene & No hospital & 1970 & Low $\%$ blacks born in early certifiers \\
\hline Lamar & No hospital ${ }^{\mathrm{a}}$ & 1970 & Low $\%$ blacks born in early certifiers \\
\hline Quitman & No hospital & 1970 & Low $\%$ blacks born in early certifiers \\
\hline Sharkey & No hospital & 1970 & Low $\%$ blacks born in early certifiers \\
\hline Tate & No hospital & 1970 & Low $\%$ blacks born in early certifiers \\
\hline Webster & No hospital & 1970 & Low $\%$ blacks born in early certifiers \\
\hline 1tawamba & 1969 & --- & Missing black vital statistics data \\
\hline Tishomingo & 1969 & -..- & Missing black vital statistics data \\
\hline
\end{tabular}


$25217 ?$ 

Date Due 



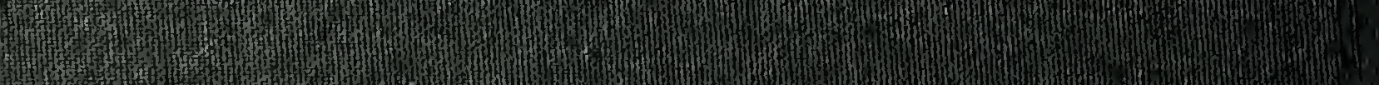

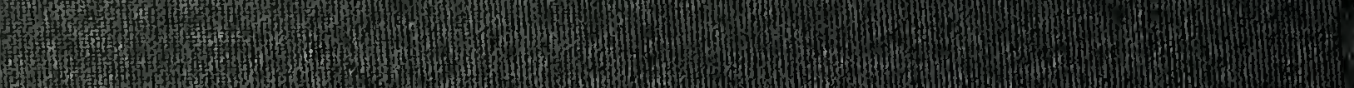
mat

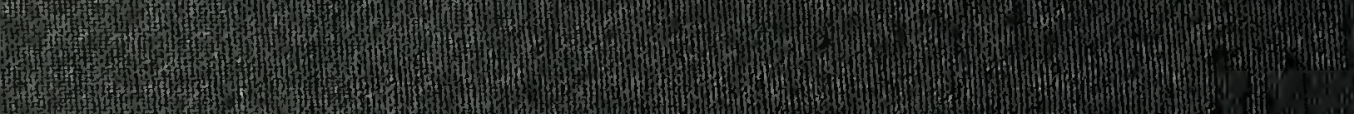

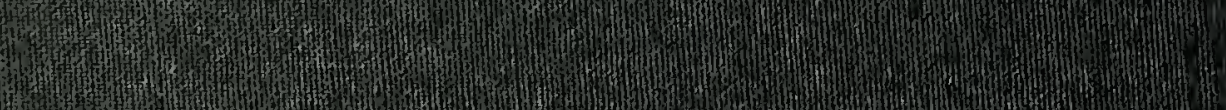

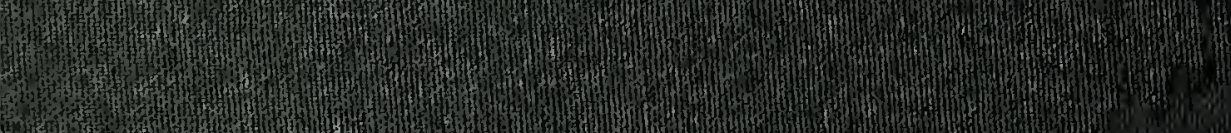

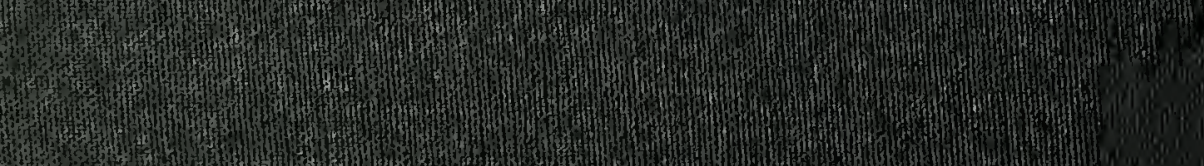

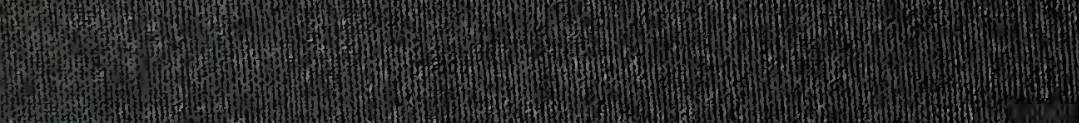
H.1.

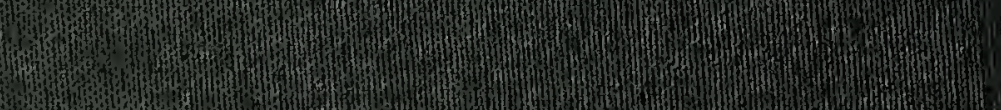

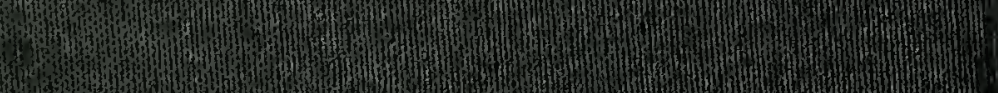
-34.

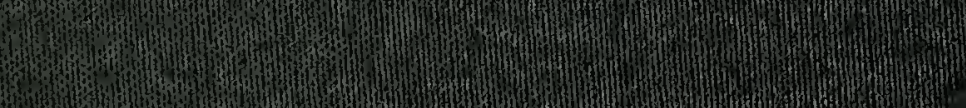

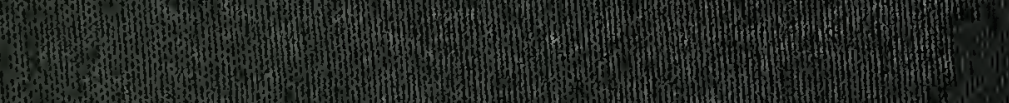
-1.

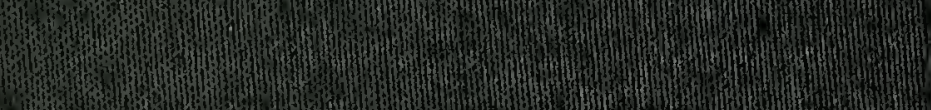

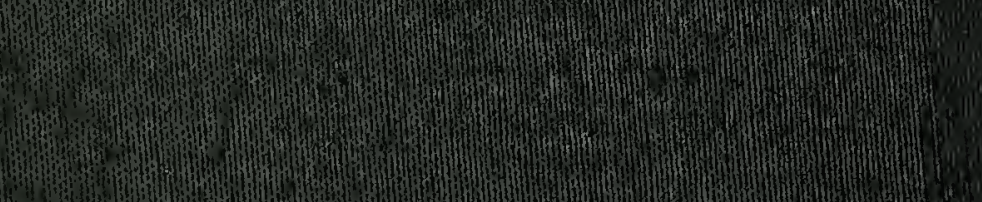
4.

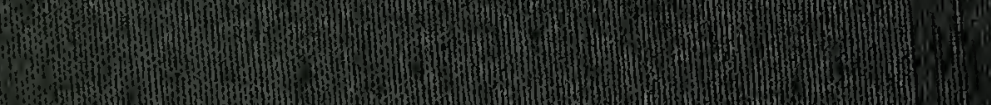
1
4

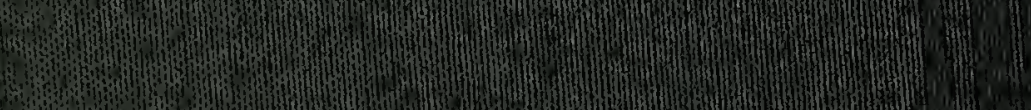

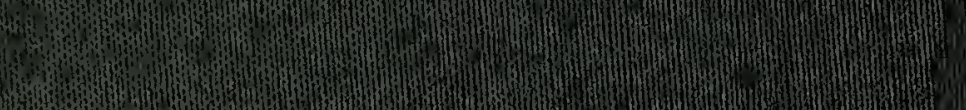
(1)

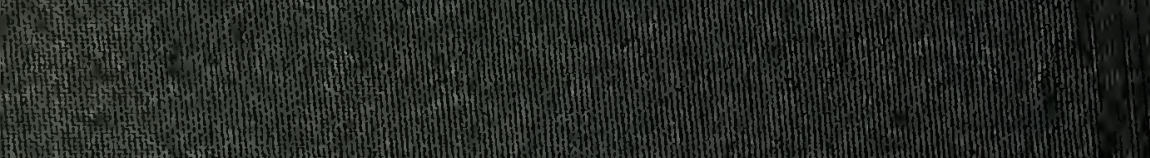

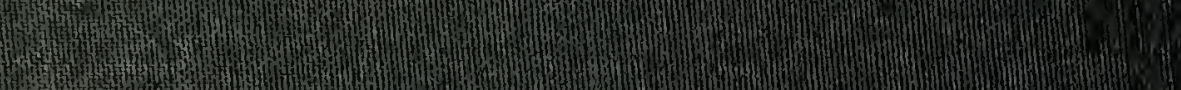
4.

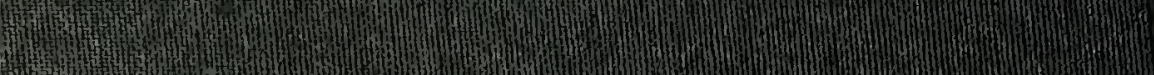

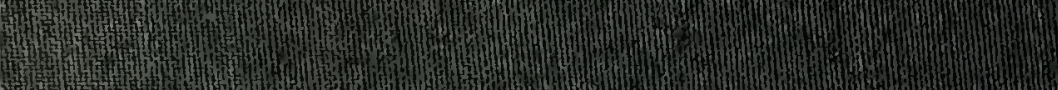

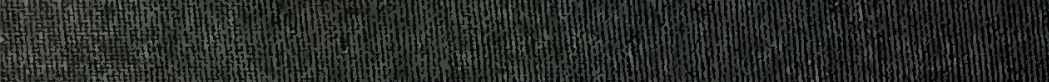

